$7-1-2012$

\title{
Religious Freedom and Inmate Grooming Standards
}

Dawinder S. Sidhu

University of New Mexico - School of Law

Follow this and additional works at: https://digitalrepository.unm.edu/law_facultyscholarship

Part of the Law and Race Commons

\section{Recommended Citation}

Dawinder S. Sidhu, Religious Freedom and Inmate Grooming Standards, 66 University of Miami Law Review 923 (2012).

Available at: https://digitalrepository.unm.edu/law_facultyscholarship/265

This Article is brought to you for free and open access by the UNM School of Law at UNM Digital Repository. It has been accepted for inclusion in Faculty Scholarship by an authorized administrator of UNM Digital Repository. For more information, please contact amywinter@unm.edu, Isloane@salud.unm.edu,sarahrk@unm.edu.

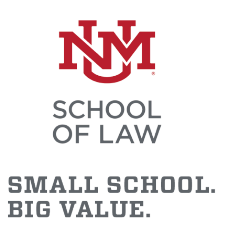

BIG VALUE. 


\title{
Religious Freedom and Inmate Grooming Standards
}

\author{
DAWINDER S. SiDHU $\dagger$
}

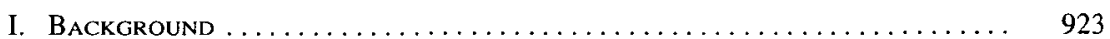

II. Introduction to Applicable Law and Institutional IntERESTS ........ 930

A. Governing Legal Provisions and Policies ..................... 930

B. Penological Concerns .............................. 935

C. Inmate Rights ...................................... 938

D. The Role of the Courts................................ 940

III. Eleventh Circuit Jurisprudence on Religious-Based Challenges to

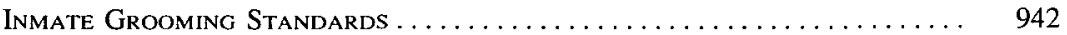

A. Early Free Exercise Cases ................................. 942

B. Major Doctrinal Guideposts .......................... 944

C. Modern Post-RLUIPA Case ........................... 946

IV. An Argument for an Alternative Approach to the Elleventh Circuit's Deferential Support of Restrictive Inmate Grooming Policies . . ..... 947

A. General Principles ................................. 947

B. Impact of Medical Exemptions on Inmate Grooming Policies ......... 950

C. Impact of Other Jurisdictions' Permissive Grooming Policies .......... 954

D. Compliance with RLUIPA .............................. 958

V. Conclusion ......................................... 961

Appendix A: Image of Alabama Personal Appearance Policies . . . . . . . . . . . . . 963

Appendix B: Federal and State Inmate Grooming Policies . . . . . . . . . . . . . . . 964

\section{BACKGROUND}

The Framers, acutely aware of settlers' experiences with religious intolerance in England and the colonies, established a republic in which religious freedom would be shielded from governmental interference or intrusion. ' The Free Exercise Clause of the First Amendment to the U.S. Constitution embodies this philosophical promise and pragmatic guarantee, declaring that "Congress shall make no law ... prohibiting the free

$\dagger$ Assistant Professor of Law, University of New Mexico School of Law; J.D., The George Washington University; M.A., Johns Hopkins University; B.A., University of Pennsylvania. My thanks to Seval Yildirim for her critical guidance; Bahar Ansari, Art Minas, Tyler McCormick, and Douglas Spoerl, for their invaluable research assistance in preparing Appendix B; the staff of the law review, including Emily Horowitz and Tal Lifshitz, for improving the quality and readability of this piece; and my parents for their encouragement and support. Please excuse any errors, which rest with and should be attributed to me.

1. See Bowen v. Roy, 476 U.S. 693, 703 (1986) ("historical instances of religious persecution and intolerance . . g gave concern to those who drafted the Free Exercise Clause" of the First Amendment to the U.S. Constitution); Buckley v. Valeo, 424 U.S. 1, 93 n.127 (1976) ("Intolerable persecutions throughout history led to the Framers' firm determination that religious worship both in method and belief must be strictly protected from government intervention.") (per curiam). 
exercise of [religion.]"2

The Supreme Court repeatedly has understood the special origins of this substantive right and the unique role that religious freedom has in our constitutional tradition and social fabric. Justice Robert H. Jackson noted that "[t]he history of religious persecution" explains why "the First Amendment separately mention[s] free exercise of religion." Elsewhere, the Court observed that " $[\mathrm{t}]$ he place of religion in our society is an exalted one, achieved through a long tradition of reliance on the . . . inviolable citadel of the individual heart and mind. We have come to recognize through bitter experience that it is not within the power of the government to invade that citadel[.]"4

Religious freedom, while robust, is not without limits. The First Amendment "embraces two concepts, [the] freedom to believe and [the] freedom to act." Whereas the first is "absolute,"6 the second "is not."7 As to the former, in his seminal text, A Bill for Establishing Religious Freedom, Thomas Jefferson, perhaps the most influential and persuasive advocate of religious liberty among the founding generation, ${ }^{8}$ stated that "[t]he opinions of men are not the object of civil government, nor under its jurisdiction."

With respect to acts, by contrast, individual religious conduct may

2. U.S. Const, amend. I. This requirement applies to the States. See Cantwell v. Connecticut, 310 U.S. 296, 303 (1940); see generally Akhil Reed Amar, The Bill of Rights as a Constitution, 100 Y ALE L.J. 1131, 1 I59 (1991) ("[T]he free exercise clause was paradigmatically about citizen rights, not state rights; it thus invites incorporation.").

3. Douglas v. City of Jeannette, 319 U.S. 157, 179 (1943) (Jackson, J., concurring in result).

4. Sch. Dist. v. Schempp, 374 U.S. 203, 226 (1963); see also Sherbert v. Verner, 374 U.S 398,413 (1963) (Stewart, J., concurring) ("I am convinced that no liberty is more essential to the continued vitality of the free society which our Constitution guarantees than is the religious liberty protected by the Free Exercise Clause of the First Amendment . . .."); James Madison, Memorial and Remonstrance Against Religious Assessment (1785), available at http://religiousfreedom. lib.virginia.edu/sacred/madison_m\&r_1785.html (objecting to the use of "Religion as an engine of Civil policy").

5. Cantwell, 310 U.S. at 303.

6. Id.; see also Bob Jones Univ. v. United States, 461 U.S. 574, 603 (1983) ("This Court has long held the Free Exercise Clause of the First Amendment to be an absolute prohibition against governmental regulation of religious beliefs.").

7. Cantwell, 310 U.S. at 304; see also Bob Jones Univ., 461 U.S. at 603 ("[T]he Free Exercise Clause provides substantial," but not total, "protection for lawful conduct grounded in religious belief.").

8. See, e.g., Michael W. McConnell, The Origins and Historical Understanding of Free Exercise of Religion, 103 HARv. L. REv. 1409, 1431 (1990) ("Jefferson's bill . . was one of the major precursors of the religion clauses of the first amendment. Four of the five states used language from Jefferson's bill in their proposals for a religion amendment."); $i d$. at 1451 ("It was in reliance on Jefferson that the Supreme Court later held that there can be no free exercise right to exemption from a generally applicable law when such laws are directed at actions and not opinions.") (citing Reynolds v. United States, 98 U.S. 145, 164 (1878)).

9. Schneider v. Smith, 390 U.S. 17, 25 (1968) (quoting Thomas Jefferson, A Bill for Establishing Religious Freedom, JefFERSONIAN CYCLOPEDIA 976 (1900)); see also Madison, 
not only conflict with, but under certain circumstances must give way to, countervailing state interests. ${ }^{10}$ Indeed, the Supreme Court "has rejected challenges under the Free Exercise Clause to governmental regulation of certain overt acts prompted by religious beliefs or principles," where "the conduct or actions so regulated have invariably posed some substantial threat to public safety, peace, or order." "For example, the Court has upheld state limitations on religious freedom where individuals claimed the right to deny a child a compulsory vaccination for communicable disease, ${ }^{12}$ to participate in a plural relationship, ${ }^{13}$ or to engage in polygamy. ${ }^{14}$ The Court also has held that individual religious expression must cede to state interests in "eradicating racial discrimination in education," 15 preserving "the fiscal vitality of the social security system," 16 and maintaining a "fair, evenhanded, and uniform" conscription system such that the military has sufficient manpower. ${ }^{17}$

In the realm of religious expression, as in other areas of individual rights, "context matters."18 This Article concerns the tension between individual religious expression and state interests in the penal contextthe social space where individual rights generally are at their lowest ebb. ${ }^{19}$ In particular, this Article explores the extent to which an inmate

supra note 4 ("The Religion . . . of every man must be left to the conviction and conscience of every man.").

10. See United States v. Lee, 455 U.S. 252,257 (1982) ("The state may justify a limitation on religious liberty by showing that it is essential to accomplish an overriding governmental interest."); Wisconsin v. Yoder, 406 U.S. 205, 215 (1972) ("[O]nly those interests of the highest order," such as public order or safety, "can overbalance legitimate claims to the free exercise of religion.").

11. Sherbert v. Vemer, 374 U.S. 398, 403 (1963) (citations omitted); see generally Laura Underkuffler-Freund, The Separation of the Religious and the Secular: A Foundational Challenge to First Amendment Theory, 36 WM. \& MARY L. REv. 837, 923 (1995) ("Even those who argued that religious expression must be given a broad gauge, recognized that it could not be absolute. In an organized society, religious expression, like all other individual acts, must be constrained by the fundamental needs of social order. This outer limit was generally expressed in terms of 'peace,' 'safety,' and the reciprocal rights of others.").

12. Prince v. Massachusetts, 321 U.S. 158, 166-67 (1944).

13. Cleveland v. United States, 329 U.S. 14, 20 (1946).

14. Reynolds v. United States, 98 U.S. 145, 166 (1878).

15. Bob Jones Univ. v. United States, 461 U.S. 574, 604 (1983).

16. United States v. Lee, 455 U.S. 252, 258 (1982).

17. Gillette v. United States, 401 U.S. 437,455 (1971).

18. See Cutter v. Wilkinson, 544 U.S. 709, 722-23 (2005) (citing Grutter v. Bollinger, 539 U.S. 306,327 (2003)) (reviewing statutory claims that state prison officials failed to accommodate religious practices).

19. See Hydrick v. Hunter, 500 F.3d 978, 989 (9th Cir. 2007) ("the rights afforded prisoners set a floor for those" available to others), vacated by 129 S. Ct. 2431 (2009) (remanding for consideration of a Supreme Court decision issued subsequent to the Ninth Circuit's ruling); Fred Cohen, Captives' Legal Right to Mental Health Care, 17 Law \& Psychol. Rev. 1, 1 (1993) (observing that prison inmates "occupy[] the lowest rung on the legal rights ladder"); see also Garrett Epps, Strip Search for a Minor Offense: Is It Constitutional?, THE ATLANTIC, Oct. 13, 
may maintain his or her hair for religious reasons despite prison grooming policies limiting or prohibiting inmates from growing facial hair or keeping long hair. Prison officials justify such policies on various grounds, including the need to properly identify inmates, ensure optimal health and sanitation, eliminate markers of gang affiliation, and promote order. $^{20}$

The U.S. Court of Appeals for the Eleventh Circuit is among the federal courts that have issued opinions in this legal field. In challenges brought by inmates under the Free Exercise Clause or its statutory analogue in the prison context, the Religious Land Use and Institutionalized Persons Act ("RLUIPA"), ${ }^{21}$ the Eleventh Circuit has routinely sided with prisons and specifically validated the restrictive inmate grooming policies of states within its jurisdiction-Alabama, Florida, and Georgia. ${ }^{22}$ The court, more specifically, accepts the states' penological interests as compelling and the restrictive grooming policies as the least restrictive means to further those interests. Joining the Eleventh Circuit on the restrictive end of the spectrum are other courts of appeals, most notably the Fourth, Fifth, and Eighth. ${ }^{23}$ The federal appellate courts are not, however, in agreement. The Ninth Circuit, for example, has taken the opposite position, striking down restrictive grooming policies as an infringement on inmate religious freedom. ${ }^{24}$

The legal landscape in this area is not only split, but is facing transformation. The Eleventh Circuit is affected by, and may even lie at the heart of, this changing dynamic. In 2011, the Department of Justice intervened in federal circuit and district court cases pending in Alabama,

2011, available at http:/www.theatlantic.com/national/archive/2011/10/strip-search-for-a-minoroffense-is-it-constitutional/246581 ("[our] society [is] enamored of incarceration, which aims to turn any prisoner into an item who can be processed and controlled with minimal fuss about rights and privacy."). The limited rights of prisoners are discussed in greater detail in Part II.C, infra.

20. See Part II.B, infra.

21. 42 U.S.C. $\$ \S 2000 c c-2000 c c-5$ (2000).

22. In this Article, "restrictive grooming policies" are generally those policies in prison facilities that require inmates to shave, trim, or cut their hair without religious exceptions.

23. See DeMoss v. Crain, 636 F.3d 145, 153-54 (5th Cir. 2011); Iron Hines v. S.C. Dep't of Corr., 148 F.3d 353, 357-58 (4th Cir. 1998); Eyes v. Henry, 907 F.2d 810, 814 (8th Cir. 1990).

24. See Warsoldier v. Woodford, 418 F.3d 989, 1001 (9th Cir. 2005). For a case demonstrating the courts' historic understanding of the importance of religious exercise and restrictive inmate grooming standards, see Ho Ah Kow v Nunan, 12 F. Cas. 252, 253 (C.C.D. Cal. 1879) ("The maltreatment consisted in having wantonly and maliciously cut off the queue of the plaintiff, a queue being worn by all Chinamen, and its deprivation being regarded by them as degrading and as entailing future suffering."); id. at 254 ("A treatment to which disgrace is attached, and which is not adopted as a means of security against the escape of the prisoner, but merely to aggravate the severity of his confinement, can only be regarded as a punishment additional to that fixed by the sentence. If adopted in consequence of the sentence it is punishment in addition to that imposed by the court; if adopted without regard to the sentence it is wanton cruelty."). 
California, and Texas, arguing in favor of the Ninth Circuit's permissive, inmate-rights approach to prisoner challenges to inmate grooming standards, rather than the Eleventh Circuit's more deferential, prisoncentric take. ${ }^{25}$ The California state prison system, which houses approximately 144,000 inmates, ${ }^{26}$ ultimately settled its case, deciding generally to withdraw its restrictive policies and allow inmates to maintain beards and long hair for religious purposes, notwithstanding institutional needs for security, health, and order. ${ }^{27}$

In doing so, California became one of thirty-nine states-along with the Federal Bureau of Prisons, the largest prison system with over 208,000 inmates, ${ }^{28}$ and the District of Columbia-to adopt permissive grooming policies or grant religious exemptions to such grooming policies. ${ }^{29}$ By contrast, the states within the Eleventh Circuit are among the minority of states, eleven to be exact, which apply restrictive grooming policies to inmates with religious beliefs requiring long or unshorn hair. ${ }^{30}$

In this Article, I argue that the Eleventh Circuit's general legal approach to such religious freedom claims and its support for restrictive inmate grooming standards are no longer sustainable. That is, a substantial and increasing number of jurisdictions have been able to respond to their penological concerns-the same penological interests that undergird and justify the restrictive inmate grooming standards adopted by the states within the Eleventh Circuit-without abridging the rights of inmates to grow their hair in accordance with their respective faiths.

25. See Statement of Interest of the United States at 2, Limbaugh v. Thompson, No. 2:93cv1404-WHA (M.D. Ala. Apr. 8, 2011); Complaint in Intervention Pursuant to the Religious Land Use and Institutionalized Persons Act, 42 U.S.C. $\$ 2000$ (c) (Civil Rights) at 7, Basra v. Cate, No: CV11-01676 SVW (C.D. Cal. Mar. 15, 2011); Brief for the United States as Amicus Curiae, Garner v. Kennedy, No. 11-40653 (5th Cir. Dec. 27, 2011) [hereinafter "Department of Justice Garner Amicus Brief"]. In 2010, the Department of Justice also responded to a request from the Supreme Court for the Solicitor General's views on whether certiorari should be granted in a case brought by a Native American inmate who sought to maintain long hair, as his religion required, despite Texas's restrictive grooming policies. See Brief for the United States as Amicus Curiae at 7-8, Thunderhorse v. Pierce, No. 09-1353 (S. Ct. Dec. 1, 2010) [hereinafter "Department of Justice Thunderhorse Amicus Brief"] (the Fifth Circuit's failure to "requir[e] respondent [prison director] to address record evidence that tended to show that prison officials potentially could further compelling governmental interests through less restrictive means" is a "case-specific error [that] does not [itself] warrant plenary review by this Court."), cert. denied, $131 \mathrm{~S}$. Ct. 896 (2011).

26. See Jennifer Medina, California Begins Moving Prison Inmates, N.Y. Times, Oct. 8, 2011, at A14, available at http://www.nytimes.com/2011/10/09/us/california-begins-movingprisoners.html.

27. See Settlement Agreement at Tाt 9-10, Basra v. Cate, No. CV11-01676 SVW, Doc. \#40-1 (C.D. Cal. June 5, 2011) [hereinafter "Basra Settlement"].

28. See The Pew Center on the States, Prison Count 2010, at 7 (Apr. 2010), available at http://www.pewcenteronthestates.org/uploadedFiles/Prison_Count_2010.pdf.

29. See infra Appendix B.

30. See id. 
Accordingly, I posit that the Eleventh Circuit's jurisprudence must not only be revisited, but replaced with a more searching analysis, in light of the prevailing, and growing recognition that religious rights of inmates need not reflexively give way to prison interests in security, health, and order. Framed differently, to the extent that an individual imprisoned in a state within the Eleventh Circuit asserts that the applicable grooming standards implicate an inmate's religious rights, the Eleventh Circuit may be obliged to change course and examine with greater scrutiny and skepticism the states' ability under law to enforce restrictive grooming policies.

I make this argument in three steps. I will first provide an overview of the constitutional and statutory provisions that are relevant to claims of religious freedom in the inmate grooming context, specifically the legal standards under the Free Exercise Clause and RLUIPA; the penological interests that states with restrictive policies invoke to explain the need for their respective grooming requirements; the scope of individual religious rights, which are generally limited in the penal environment; and finally, the role of the courts in assessing prison regulations and assertions of religious freedom by inmates.

Second, with an understanding of the relevant law and policies, I will proceed to summarize the rulings issued by the Eleventh Circuit in this area of law. And third, I discuss the recent developments that particularly call into question the Eleventh Circuit's deferential stance on the religious rights of inmates with respect to restrictive grooming policies. Given this foundation, I argue that the Eleventh Circuit's strident defense of its states' restrictive grooming policies can no longer stand, and that as a commensurate consequence, it must bring itself in line with the doctrinal interpretation of other courts and the Department of Justice that demand a closer look into the need for restrictive grooming standards as applied to specific inmates.

At bottom, the legal principle that I offer and advance in this Article is this: that restrictive grooming policies can no longer be imposed on inmates with sincere religious beliefs that require adherents to wear beards or long hair, unless the state has a particularized evidentiary basis that the specific plaintiffs or inmates in question pose an actual or threatened risk to the state's compelling penological interests. It is this principle that the Eleventh Circuit should adopt and that finds support in precedent, existing penal policies, and the progress of the law in this field. It diverges with the Eleventh Circuit's current approach which has the following principal deficiencies that are symptomatic of excessive deference to the prison authorities: the approach does not ask why the states need restrictive grooming policies where a vast majority of juris- 
dictions do not resort to restrictive grooming policies despite having the same penological interests, does not push states on why the issuance of medical exemptions to restrictive grooming policies does not undermine the argument that religious exemptions cannot be similarly provided, and does not demand any evidence that the inmates requesting religious accommodations themselves have given rise to the penological concerns justifying the restrictive grooming policies.

The suggestion that a federal circuit court is out of step with other courts and with the Department of Justice may, on its own, justify a serious inquiry as to the nature of the split, the merits of the different views, and which camp the arc of the law should move towards. Consistency among the courts is valuable and is a legal and social good in itself. It is particularly necessary to seek harmony among the courts where a circuit court may be unduly depriving individuals of rights, including the freedom to practice one's religion. The Department of Justice's recent and active participation in multiple cases also signals the importance of this particular issue and reflects the agency's perception that it is in need of clarity. ${ }^{31}$ The diverging views in the courts and the Department of Justice's affirmative involvement point to the possibility that the Supreme Court may be called upon to issue a single, uniform standard that will apply to all prison facilities.

This Article may help define what that ultimate standard should be-if the one I propose is satisfactory, if a similar alternative is more preferable, or if the solution lies completely elsewhere. It is hoped, moreover, that this Article, given recent advancements, will be useful for the bar and bench in shaping the direction of the Eleventh Circuit's future cases in this area, and for states within the Eleventh Circuit in effectively responding to potential legal attacks on their grooming policies. ${ }^{32}$

What follows is my modest attempt to achieve these objectives and enrich legal and public understanding of the permissibility of prison grooming standards that conflict with the religious requirements of incarcerated individuals.

\footnotetext{
31. In fact, several federal courts have noted, in the context of qualified immunity, that inmates may not be able to recover damages against prison officials for RLUIPA violations. See Farrow v. Stanley, No. Civ.02-567-PB, 2005 WL 2671541 , at *11 n. 13 (D.N.H. Oct. 20, 2005) (discussing 42 U.S.C. $\$ 2000 \mathrm{cc}-2$ and commenting on the "substantial uncertainty . . a to whether [RLUIPA] even provides a right to money damages."); see also Bryan v. Capers, No. 8:06-cv-2515-GRA-BHH, 2007 WL 2116452, at *6 n.4 (D.S.C. July 19, 2007) (acknowledging the "uncertainty" and listing other cases that address it).

32. For an "anti-oppression" theory response to inmate grooming policies, based on equal protection and Free Exercise principles, see generally Mara R. Schneider, Note, Splitting Hairs: Why Courts Uphold Prison Grooming Policies and Why They Should Not, 9 MicH. J. RACE \& L. 503 (2004).
} 


\section{II: INTRODUCTION TO APPLICABLE LAW AND INSTITUTIONAL INTERESTS}

\section{A. Governing Legal Provisions and Policies}

Inmates challenging prison grooming policies on religious freedom grounds have available to them constitutional and statutory vehicles for relief. A brief summary of these provisions and how they differ is in order.

The Free Exercise Clause is the explicit constitutional instrument safeguarding religious freedom from governmental intrusion or interference. It provides that "Congress shall make no law . . . prohibiting the free exercise [of religion.]" 33 In general terms, individuals seeking religious-based exemptions to neutral, generally applicable government laws or policies, including prison grooming standards, may, at least theoretically, rely on this express constitutional guarantee. Practically, however, the Free Exercise Clause has not served as a robust protection against federal or state encroachments on religious freedom. Individuals pursuing such constitutional claims also face a patchwork of standards that have evolved over time and that are of one type for the federal government and are of multiple variations among the states. This situation, and the limited force of the Free Exercise Clause more broadly, helps explain why Congress enacted statutory remedies to bolster individual religious freedom from state regulation in prisons.

As a historical matter, the Free Exercise Clause was read to require an exemption to generally applicable government policies in quite limited circumstances, that is, only if the statute or policy expressly provided for one. ${ }^{34}$ In 1963, however, a landmark Free Exercise ruling was issued. The Supreme Court held in Sherbert v. Verner that a sincere religious objector ${ }^{35}$ is entitled to an exemption from a generally applica-

33. U.S. Const. amend. I. As noted above, supra note 2, the Free Exercise Clause has been incorporated against the States. For a discussion of earlier drafts of this guarantee, see Lee $v$. Weisman, 505 U.S. 577, 612-15 (1992) (Souter, J., concurring) (tracking the development of the religion clause from " $[t]$ he civil rights of none shall be abridged on account of religious belief or worship, nor shall any national religion be established, nor shall the full and equal rights of conscience be in any manner, or on any pretext, infringed" to its current form) (citation omitted) (alteration in original).

34. See Eugene Volokh, A Common-Law Model for Religious Exemptions, 46 UCLA L. REv. 1465, 1473 (1999) ("When should such exemptions be granted, and who should decide when they should be granted? Until 1963, the general answer seemed to be that the matter was up to the legislature ....").

35. The beliefs need not be longstanding, central to the claimant's religious beliefs, internally consistent, consistent with any written scripture, or reasonable from the judge's perspective. They need only be sincere. See Thomas v. Review Bd. of Ind. Emp't Sec. Div., 450 U.S. 707, 716 (1981) ("[1]t is not within the judicial function and judicial competence to inquire whether the petitioner or his fellow worker more correctly perceived the commands of their common faith. Courts are not arbiters of scriptural interpretation."); Baker v. Home Depot, 445 F.3d 54 I, 547 (2d 
ble law that imposes a substantial burden on the individual's exercise of his or her religion, unless the law in question survives strict scrutiny ${ }^{36} \mathrm{~A}$ substantial burden is generally defined as either compelling an individual to do that which violates his or her religious beliefs or prohibiting an individual from that which is mandated by his or her religious beliefs. ${ }^{37}$

After Sherbert, the Court issued several opinions respecting the First Amendment rights of prisoners. In 1972, the Court stated in Cruz v. Beto that "reasonable oportunities [sic] must be afforded to all prisoners to exercise the religious freedom guaranteed by the First . . . Amendment without fear of penalty." ${ }^{38}$ In Procunier v. Martinez, a 1974 case, the Court clarified that prison regulations implicating the First Amendment religious rights of incarcerated individuals must further "an important or substantial governmental interest" and "must be no greater than is necessary or essential to the protection of the particular governmental interest involved." 39

The degree to which the religious rights of incarcerated individuals were protected appeared to have diminished shortly thereafter. In Jones v. North Carolina Prisoners' Labor Union, Inc., handed down in 1977, the Court stated that a district court should have only required the prison officials to show that the state prison authorities' "beliefs" as to the necessity of the First Amendment restrictions were not "unreasonable." ${ }^{40}$ In O'Lone v. Estate of Shabazz, the Court in 1987 similarly held that a prisoner's free exercise claim will be "judged under a 'reasonableness' test less restrictive than that ordinarily applied to alleged infringements of fundamental constitutional rights." ${ }^{41}$ In Turner v. Safley, issued the same year, the Court explained that "when a prison regulation impinges on inmates' constitutional rights, the regulation is valid if it is reasonably related to legitimate penological interests." ${ }^{2}$ The Court identified "several factors [that] are relevant in determining the reasonableness of the regulation at issue," specifically whether there is "a valid, rational connection between the prison regulation and the legitimate governmental interest put forward to justify it"; "whether there are alternative means of exercising the right that remain open to prison inmates"; "the impact accommodation of the asserted constitutional right will have

Cir. 2006) ("[T]he question of the sincerity of an individual's religious beliefs is inherently within that individual's unique purview ....").

36. Sherbert v. Verner, 374 U.S. 398,403 (1963).

37. Id. at 404.

38. Cruz v. Beto, 405 U.S. 319, 322 n.2 (1972).

39. Procunier v. Martinez, 416 U.S. 396, 413 (1974).

40. Jones v. N.C. Prisoners' Labor Union, Inc., 433 U.S. 119, 127-28 (1977).

41. O'Lone v. Estate of Shabazz, 482 U.S. 342, 349 (1987).

42. Turner v. Safley, 482 U.S. 78,89 (1987). 
on guards and other inmates, and on the allocation of prison resources generally"; and whether there are "ready alternatives" to the prison regulation. ${ }^{43}$

Outside of the prison context, in the 1990 Employment Division $v$. Smith decision, the Court distinguished Sherbert and effectively reverted back to the rule in which an exemption to facially neutral laws or policies for religious reasons was required only when the statute itself carved out an exemption. ${ }^{44}$ The Court took the view that groups seeking exemptions from generally applicable laws may convince others of their need by way of the political process, but that such exemptions were not "constitutionally required." 45 Smith thus represented a tectonic shift in the Court's general Free Exercise jurisprudence.

In 1993, in response to Smith, Congress passed the Religious Freedom Restoration Act ("RFRA"), which functionally adopted the 1963 Court's standard and restored Sherbert's model. In 1997, the Court in City of Boerne v. Flores concluded that RFRA is unconstitutional as applied to the states, leaving it effective only with respect to the federal government. ${ }^{46}$

Following City of Boerne, some states enacted constitutional or statutory provisions: eleven states passed state constitutional provisions requiring laws or policies substantially burdening the religious practices

43. Id. at 89-90 (citations and internal quotation marks omitted). Though the Court does not mark this consideration as a separate factor, it nonetheless states that part of the reasonableness analysis is examining whether the governmental objective is a "legitimate and neutral one," that is whether the "prison regulations restricting inmates" First Amendment rights operate[ ] in a neutral fashion, without regard to the content of the expression." Id. at 90.

44. Emp't Div., Dep't of Human Res. of Or. v. Smith, 494 U.S. 872, 884-85 (1990). Religion clause scholar Professor Michael W. McConnell suggests that the Court in Simith improvidently changed course, and that the pre-Smith rule is "more consistent with the original understanding" of the free exercise guarantee "than is a position that leads only to the facial neutrality of legislation." McConnell, supra note 8, at 1512; see also Michael W. McConnell, Free Exercise Revisionism and the Smith Decision, 57 U. CHI. L. Rev. 1109, 1144-45 (1990).

45. Smith, 494 U.S. at 890 . On this point, Justice O'Connor disagreed that exemptions for religious practices should be left to the political process. See id. at 902 (O'Connor, J., dissenting) ("[T]he First Amendment was enacted precisely to protect the rights of those whose religious practices are not shared by the majority and may be viewed with hostility. The history of our free exercise doctrine amply demonstrates the harsh impact majoritarian rule has had on unpopular or emerging religious groups ....."); see id. at 903 ("The very purpose of a Bill of Rights was to withdraw certain subjects from the vicissitudes of political controversy, to place them beyond the reach of majorities and officials and to establish them as legal principles to be applied by the courts. One's right to life, liberty, and property, to free speech, a free press, freedom of worship and assembly, and other fundamental rights may not be submitted to vote; they depend on the outcome of no elections.") (quoting W. Va. State Bd. of Educ. v. Barnette, 319 U.S. 624, 638 (1943)).

46. City of Boerne v. Flores, 521 U.S. 507, 536 (1997); see also Cutter v. Wilkinson, 544 U.S. 709, 715 n.2 (2005) ("RFRA, Courts of Appeals have held, remains operative as to the Federal Government and federal territories and possessions."). 
of employees to survive strict scrutiny, as in RFRA; New York enacted a state constitutional provision requiring intermediate, not strict, scrutiny; and fifteen states adopted statutory equivalents to the RFRA. The remaining states adhere to Smith's statutory exemption model..$^{47}$ Though a full critique of the differing levels of protections afforded to individuals seeking religious exemptions to generally applicable laws and policies is beyond the scope of this Article, it is worth noting that scholars have argued that this "situation, in which some religious practices of some citizens are governed by [the 1990 rule], and some by the tougher standard of . . RFRA, creates an unacceptable inequality in access to fundamental liberties." 48

In 2000, following City of Boerne, Congress passed RLUIPA, ${ }^{49}$ a clear effort to reinstate heightened protection of religious freedom in the prison context. ${ }^{50}$ While the substantive goals of RFRA and RLUIPA are comparable, their sources of constitutional authority differ. Whereas RFRA was enacted pursuant to Congress's Fourteenth Amendment enforcement power and subsequently struck down as exceeding this authority, ${ }^{51}$ RLUIPA was passed under Congress's commerce and spending powers, and whether it is a valid exercise of Congress's Article I authority has not been placed into doubt by the Supreme Court. ${ }^{52}$

RLUIPA provides, in relevant part, that "[n]o government shall impose a substantial burden on the religious exercise of a person residing in or confined to an institution ... even if the burden results from a rule of general applicability," unless the burden (1) "is in furtherance of

47. See Eugene Volokh, Some Background on Religious Exemption Law, The VolokH ConsPIRACY (June 12, 2010, 19:07 EST), http://volokh.com/2010/06/12/some-background-onreligious-exemption-law-2/ (June 12, 2010, 19:07 EST); Eugene Volokh, Religious Exemption Map of the United States, The VolokH Conspiracy (July 9, 2010, 17:36 EST), http://volokh. $\mathrm{com} / 2010 / 07 / 09 /$ religious-exemption-law-map-of-the-united-states/.

48. Martha C. Nussbaum, Deliberation and Insight: Bloch v. Frischholz and the "Chicago School" of Judicial Behavior, 77 U. CHI. L. REv. 1139, 1158-59 (2010).

49. See 42 U.S.C. $\$ \S 2000 \mathrm{cc}-2000 \mathrm{cc}-5$ (2000).

50. Sossamon v. Texas, 131 S. Ct. 1651, 1655-56 (2011) ("RLUIPA is Congress' second attempt to accord heightened statutory protection to religious exercise in the wake of this Court's decision in $[S m i t h]$.... We held RFRA unconstitutional as applied to state and local governments because it exceeded Congress' power under $\S 5$ of the Fourteenth Amendment. Congress responded by enacting RLUIPA ...."); Cutter, 544 U.S. at 714 ("RLUIPA is the latest of longrunning congressional efforts to accord religious exercise heightened protection from governmentimposed burdens . . . "); see also River of Life Kingdom Ministries v. Vill. of Hazel Crest, 611 F.3d 367, 378 (7th Cir. 2010) (characterizing RLUIPA as part of a "decade-long tug of war between Congress and the Supreme Court over the protection of religious liberty.").

51. See Flores, 521 U.S. at $516,536$.

52. See 42 U.S.C. $\$ \S 2000 \mathrm{cc}(\mathrm{a})(2), 2000 \mathrm{cc}-1$ (b) (2000). The Eleventh Circuit has construed RLUIPA to "hinge[ ] on Congress' Spending Power, rather than its Commerce Clause Power." Smith v. Allen, 502 F.3d 1255, 1274 n.9 (1 lth Cir. 2007), abrogated on other grounds; Sossamon, $131 \mathrm{~S}$. Ct. at 1656 (declining to address whether the Commerce Clause or Spending Clause permitted Congress to enact RLUIPA). 
a compelling governmental interest"; and (2) "is the least restrictive means of furthering that compelling governmental interest." 53 Given its stricter standard, and Smith's alleged "emasculation" of free exercise, ${ }^{54}$ RLUIPA is, understandably, the preferred avenue for relief for inmates demanding religious exemptions to or contesting the validity of state prison grooming policies. ${ }^{55}$

As to its other particulars, "religious exercise" under RLUIPA is defined broadly to include "any exercise of religion, whether or not compelled by, or central to, a system of religious belief." 56 An incarcerated individual keeping his or her hair for religious reasons would fall squarely within this category of protected expression contemplated by the statute. ${ }^{57}$

A plaintiff bringing a RLUIPA claim bears the initial burden of proving the existence of a "substantial burden." ${ }^{\text {" R }}$ RUIPA leaves open the meaning of a "substantial burden," 59 compelling the courts to fashion their own workable definition of the term. ${ }^{60}$ The Eleventh Circuit understands "substantial burden" to mean that which "place[s] more than an inconvenience on religious exercise," such as "significant pressure which directly coerces the religious adherent to conform his or her behavior accordingly." ${ }^{1}$ In other words, the court has stated, "[A] substantial burden can result from pressure that tends to force adherents to forego religious precepts or from pressure that mandates religious conduct." 62

It is beyond dispute that a prison grooming policy that would restrict or forbid an inmate from growing his or her hair, where an inmate's religion mandates that such hair be maintained, directly interferes with a cognizable religious exercise and that this conflict repre-

53. 42 U.S.C. $\$ 2000 \mathrm{cc}-1(2000)$.

54. See, e.g., The Supreme Court, 1989 Term-Leading Cases, 104 Harv. L. Rev. 198, 204 (1990) (Smith "effectively abandons the fundamental liberty of religious conscience" embodied in the Free Exercise Clause).

55. Accordingly, as it is the primary tool for litigation in this area and is invariably the emphasis of resulting court opinions, RLUIPA is emphasized in this Article as compared to the Free Exercise Clause.

56. 42 U.S.C. $\$ 2000 \mathrm{cc}-5(7)(\mathrm{A})(2000)$.

57. See infra notes $97-104$ and accompanying text.

58. 42 U.S.C. $\S 2000$ cc-2(b) (2000).

59. See 42 U.S.C. $\$ 2000$ cc-5 (2000) (definitions); see also 146 Cong. Rec. S7776 (daily ed. July 27,2000 ) ("it is not the intent of [RLUIPA] to create a new standard for the definition of 'substantial burden' on religious exercise."); 146 Cong. REC. S7776 (daily ed. July 27, 2000) (joint statement of Sens. Hatch \& Kennedy) ("substantial burden" should be interpreted with reference to the Supreme Court's jurisprudence as to "the concept of substantial burden or religious exercise.").

60. See Midrash Sephardi, Inc. v. Town of Surfside, 366 F.3d 1214, 1226 (11 th Cir. 2004).

61. Id. at 1227 .

62. Id.; accord Cruz v. Beto, 405 U.S. 319, 322 (1972). 
sents a "substantial burden" within the meaning of RLUIPA. ${ }^{63}$ The core question therefore becomes whether the prison officials can meet their burden of proving that they possess a compelling state interest in instituting a restrictive grooming policy and whether the policy itself is the least restrictive means to further that interest. ${ }^{64}$

\section{B. Penological Concerns}

As a general matter, prison officials possess significant authority to manage prisons given the distinctive circumstances of penal settings and the pressing needs in them. The Supreme Court, for example, observed that correctional facilities are "a unique place fraught with serious security dangers." 65 Further, the Court noted, running a prison facility is "an inordinately difficult undertaking," 66 and "the problems that arise in the day-to-day operation of a corrections facility are not susceptible of easy solutions." ${ }^{67}$ In light of the specialized issues within detention facilities, and the inherently complicated nature of prison management, the Court accords prison administrators "wide-ranging deference in the adoption and execution of policies and practices that in their judgment are needed to preserve internal order and discipline and to maintain institutional security." ${ }^{68}$ Put differently, handling such matters "is peculiarly a matter normally left to the discretion of prison administrators."

As part of its generous authority to manage the affairs within detention facilities, some prisons officials have regulated the manner in which inmates may grow or maintain their hair. ${ }^{70}$ Each of the states within the Eleventh Circuit has invoked such authority to set restrictive grooming policies for inmates and to denote possible punishment if inmates do not conform to the policies. Each state within the Eleventh Circuit also provides an exemption to such policies for medical reasons. As to its inmates, Florida mandates that:

Male inmates shall have their hair cut short to medium uniform

63. See, e.g., Smith v. Ozmint, 444 F. Supp. 2d 502, 506 (D.S.C. 2006) ("[A] policy which requires hair to be cut, and ensures compliance by force, imposes a substantial burden to one of the Rastafarian faith."); Department of Justice Garner Amicus Brief, supra note 25, at 6 ("Defendants do not dispute that th[e] ban [on growing beards] imposed a substantial burden on Garner's religious exercise.").

64. See 42 U.S.C. $\$ 2000 \mathrm{cc}-1(2000)$.

65. Bell v. Wolfish, 441 U.S. 520,559 (1979).

66. Turner v. Safley, 482 U.S. 78, 84-85 (1987)

67. Bell, 441 U.S. at 547.

68. Id. See also Cruz v. Beto, 405 U.S. 319, 321 (1972) ("We are not unmindful that prison officials must be accorded latitude in the administration of prison affairs, and that prisoners necessarily are subject to appropriate rules and regulations.").

69. Rhodes v. Chapman, 452 U.S. 337, 349 n. 14 (1981).

70. See infra Appendix B. 
length at all times with no part of the ear or collar covered. Male inmates shall be permitted to shave their entire heads in a uniform manner unless the inmate is using his hairstyle or lack thereof to demonstrate gang affiliation or otherwise pose a threat to institutional security .... Sideburns shall not extend beyond the bottom of the earlobes and will have straight lines with no flare at the base. All inmates shall be clean shaven, with the exception of [certain] inmates [with mental health classifications] ....

Additionally an exemption from the requirement to remain clean shaven shall be granted on the basis of a medical diagnosis when it is determined by the staff physician that shaving would be detrimental to the inmate's health. Inmates granted a medical exemption from the shaving requirement may be required to keep their facial hair closely trimmed with scissors or clippers. For the purposes of this rule, "closely trimmed" means trimmed so that no part of the facial hair exceeds the length prescribed by the physician as necessary to prevent the appearance or reappearance of skin disorders. If no specific length is prescribed, then facial hair shall be kept trimmed to within one-quarter inch. ${ }^{71}$

Inmates who are not in compliance with this policy are subject to discipline and prison staff may be directed "to shave the inmate or cut the inmate's hair, or take other necessary action to bring the inmate into compliance with the grooming standards."72

Georgia's grooming policies provide that:

Each inmate shall have a conventional haircut. Hair shall not be longer than three (3) inches; shall not extend beyond a point which would reach the collar on an ordinary shirt; and shall not cover any part of the ears or eyebrows. Inmates may wear sideburns no longer than a point even with the bottom of the ear canal. Mustaches are permitted, but shall not extend beyond the edge of the mouth and must be kept neat and trimmed at all times. Goatees, beards, and similar facial adornments are prohibited, unless medically indicated. ${ }^{73}$

Non-compliance with the grooming policies is considered to be a violation and may subject the offending inmate to institutional discipline. $^{74}$

Finally, with respect to Alabama's relevant grooming policies: [Inmates] are expected to maintain a good personal appearance. Male inmates are expected to be clean shaven and neat. Mustaches and beards are not permitted. There is opportunity for haircuts so

71. Fla. Admin. Code Ann. r. 33-602.101(4) (2012) (governing the care of inmates).

72. Fla. Admin. Code Ann. r. 33-602.101(5) (2012); see also Fla. Admin. Code Ann. r. 33 601.301-314 (2012) (rules pertaining to inmate discipline).

73. GA. Comp. R. \& Regs. 125-2-3-.04(6) (2010) (governing personal hygiene).

74. See GA. Comp. R. \& Regs. 125-3-2-.04(g)(3)-(5) (2010) (conduct that qualifies as a violation under the regulations). 
[inmates] can keep [their] hair well-groomed. Barbers are instructed in regard to proper haircuts and are not permitted to give special haircuts. Sideburns may be worn medium length and extended no longer than the middle of the ear. ${ }^{75}$

[Inmates may be exempted from these policies for medical reasons] based on the [decision of the state's] physician. [Exemptions] are normally issued for a certain length of time. In the case of shaving, the inmate will not be allowed to have hair longer than an 1/8th of an inch. $^{76}$

If an inmate is not following grooming policies they may receive a disciplinary citation. This citation could include a loss of priviledges [sic] such as phone or canteen use. ${ }^{77}$

These states' policies are justified and stand on four principal rationales: identification, security, health, and order. $^{78}$ Identification and $^{2}$ security are related. As an example, the Eleventh Circuit has noted that inmate grooming requirements are part of a "security rule relating to the identification of inmates in the event of escape or other incidents . . . .79 And, as Alabama has noted, "[I]f an inmate were allowed to have long hair, he could alter his appearance and thus make his identification difficult after a major incident, including escape." ${ }^{80}$ In addition to enabling positive identification, the other side of the security coin is that restrictive grooming policies are said to prevent individuals from adopting an appearance to identify or associate with a gang. ${ }^{81}$ An additional justification falling within the realm of security is that long hair or a beard may be used to conceal contraband or weapons. ${ }^{82}$ Third, such restrictive grooming policies are also said to encourage and ensure proper hygiene

75. Email from Brian Corbett, Pub. Info. Officer, Ala. Dep't of Corr., to the author (Nov. 7, 2011, 11:13AM EST) (on file with author). These Alabama personal appearance policies also contain a visual depiction of these grooming requirements. See infra Appendix A.

76. Email from Brian Corbett, Pub. Info. Officer, Ala. Dep't of Corr., to the author (Dec. 5, 2011, 07:56 EST) (on file with author).

77. Email from Brian Corbett, Pub. Info. Officer, Ala. Dep't of Corr., to the author (Dec. 13, $2011,07: 39 \mathrm{EST}$ ) (on file with author).

78. See Corbett 11/7/11 Email, supra note 75. ("Hair must be worn in proper style for health, identification, and security reasons.").

79. Solomon v. Zant, 888 F.2d 1579, 1581 (11th Cir. 1989).

80. Memorandum of Ala. Att'y Gen., Dean v. Giles, 2:07-cv-342-WKW, at 2 (M.D. Ala. Aug. 21, 2009) (No. 40).

81. See Lawson v. Dep't of Corrections, No. 4:04-cv-00105-MP-AK, 2006 WL 1737131, at *2 (N.D. Fla. June 20, 2006); $c f$. Pressley v. Madison, No. 2:08-CV-0157-RWS, 2010 WL 5313762 , at $* 3$ (N.D. Ga. Dec. 17, 2010) ("[P]rohibiting persons from wearing any form of headwear" is rationally related to "the need to maintain security, discourage potential gang activity, and facilitate the identification of inmates ...."); Daker v. Ferrero, 475 F. Supp. 2d 1325, 1350 (N.D. Ga. 2007) (prison officials "contend that headwear is frequently associated with gang identification, and thus headwear restrictions reduce the likelihood of gang violence in prison.").

82. See Harris v. Chapman, 97 F.3d 499, 504 (11th Cir. 1996). 
amongst inmates.$^{83}$ Finally, these regulations are considered to "promote order and discipline." 84

Under RLUIPA, it is necessary for a state to possess a compelling state interest in order to substantially burden an inmate's religious practices. As to the aforementioned core state interests undergirding the restrictive grooming policies, the ability to identify inmates is a compelling state interest ${ }^{85}$ and "[i]t is well established that states have a compelling interest in security and order within their prisons." ${ }^{86}$ The Eleventh Circuit also has acknowledged that ensuring the health of inmates, ostensibly including their hygiene, is a compelling state interest. ${ }^{87}$

In theory, at least, these interests can give rise to and support detention facility policies that call on inmates to cut or shave their hair. Whether these interests stand up to scrutiny and whether a facility's policies are the least restrictive means to advance the stated interests remain open questions requiring further examination.

\section{Inmate Rights}

The corollary to, or flip-side of, the prison officials' authority with respect to the operation and administration of prison facilities is the commensurately restrained rights of individual inmates. ${ }^{88}$ The Supreme Court has explained that "certain privileges and rights must necessarily be limited in the prison context." 89 "[L]awful incarceration," in other words, generally "brings about the necessary withdrawal or limitation of many privileges and rights, a retraction justified by the considerations underlying our penal system."90 This is the case even when First Amendment rights are at stake. A prisoner possesses only "those First

83. See Lawson, $2006 \mathrm{WL} 1737131$, at *2-*3.

84. Solomon, 888 F.2d at 1581-82.

85. Harris, 97 F.3d at 504; see also Green v. Polunsky, 229 F.3d 486, 490 (5th Cir. 2000) ("requir[ing] inmates to be clean-shaven and to keep their hair cut short" is "necessary for identification purposes: Without it inmates would be able to change their appearances with ease simply by shaving off their beards or cutting their hair," which "is especially relevant . . when investigating escapes or intra-prison crimes.").

86. Harris, 97 F.3d at 504 (citing Lawson v. Singletary, 85 F.3d 502, 512 (11th Cir. 1996)); see also Muhammad v. Sapp, 388 F. App'x 892, 895-96 (11 th Cir. 2010); Linehan v. Crosby, 346 F. App'x 471, 473 (11th Cir. 2009); Lathan v. Thompson, 251 F. App'x 665, 667 (11th Cir. 2007).

87. See Brunskill v. Boyd, 141 F. App'x 771, 776 (11 th Cir. 2005).

88. See generally Gowri Ramachandran, Freedom of Dress: State and Private Regulation of Clothing, Hairstyle, Jewelry, Makeup, Tattoos, and Piercing, 66 MD. L. REv. 11, 90 (2006) ("[P]risoners have many of their liberties curtailed; that is the nature of imprisonment-it punishes and rehabilitates via the exercise of control over the prisoner.").

89. Johnson v. California, 543 U.S. 499, 510 (2005).

90. O'Lone v. Estate of Shabazz, 482 U.S. 342, 348 (1987). Two eminent legal minds found this decision to be "troublesome." Michael W. McConnell and Richard A. Posner, An Economic Approach to Issues of Religious Freedom, 56 U. CHI. L. REv. 1, 34-35 n.72 (1989). 
Amendment rights that are not inconsistent with his status as a prisoner or with the legitimate penological objectives of the corrections system." 11 In short, in the words of the Court, "The fact of confinement and the needs of the penal institution impose limitations on constitutional rights, including those derived from the First Amendment, which are implicit in incarceration." 92

Accordingly, consistent with the heightened authority of prison officials and the diminished rights of inmates, including those stemming from the First Amendment, the Court has routinely sustained limitations on inmates' First Amendment rights. For example, the Court has upheld prison regulations that restrict a prisoner's ability to receive visitors, ${ }^{93}$ to correspond with other inmates, ${ }^{94}$ to receive subscription publications, ${ }^{95}$ and to attend weekly religious services. ${ }^{96}$

These circumstances-that the scales are generally tipped in favor of the prison authorities and away from the prisoner's rights, and the willingness of the Court to reject First Amendment challenges to prison regulations-do not bode well for inmates where there is a conflict between his or her religious expression and prison grooming regulations. The potential for such conflict is great, and the variety of inmates implicated by the conflict significant.

For example, "[U]ltra-Orthodox and Hasidic Jews typically wear beards and payot (side curls) as an inherent requirement of Jewish tradition." 97 One commentator notes that "Orthodox Jews do not shave any part of the beard, at any time, for any reason." 98 In addition to Jews, Sunni Muslims read the Qu'ran to command the wearing of a beard. ${ }^{99}$ "The refusal by a Sunni Muslim male who can grow a beard, to wear one is a major sin," an imam has stated. ${ }^{100}$ "Members of the Sikh faith

\footnotetext{
91. Pell v. Procunier, 417 U.S. 817,822 (1974).

92. Jones v. N.C. Prisoners' Labor Union, Inc., 433 U.S. 119, 125 (1977).

93. Overton v. Bazzetta, 539 U.S. 126, 133 (2003).

94. Shaw v. Murphy, 532 U.S. 223, 225 (2001); see also Turner v. Safley, 482 U.S. 78, 81 (1987).

95. Thornburgh v. Abbott, 490 U.S. 401, 403 (1989).

96. O'Lone v. Estate of Shabazz, 482 U.S. 342, 345 (1987).

97. Sarah Abigail Wolkinson, A Critical Historical and Legal Reappraisal of Bhatia v. Chevron U.S.A., Inc.: Judicial Emasculation of the Duty of Accommodation, 12 U. PA. J. Bus. L. 1185, 1188 (2010); see also Eric J. Zogry, Orthodox Jewish Prisoners and the Turner Effect, 56 LA. L. Rev. 905, 913 (1996) (describing the prohibition against cutting facial hair adhered to by Orthodox Jews).

98. Zogry, supra note 97 , at 913.

99. See Fraternal Order of Police Newark Lodge No. 12 v. City of Newark, 170 F.3d 359, 360 (3d Cir. 1999), cert. denied, 528 U.S. 817 (1999).

100. Id.
} 
are required to keep their hair unshorn."101 The Sikh Code of Conduct "lists unshorn hair as the first article of faith," and identifies "dishonoring the hair" as the first forbidden practice of a Sikh. ${ }^{102}$ Rastafarians also are not permitted to shave or cut their hair. ${ }^{103}$ "A fundamental tenet of the religion is that a Rastafarian's hair is not to be combed or cut ...."104

\section{The Role of the Courts}

The courts, perhaps unsurprisingly based on the foregoing, have been quite deferential to prison officials in reviewing prison policies. That is, the Supreme Court has stated that courts have a "very limited role ... in the administration of detention facilities." 105 This is for two principal, independent reasons. The first relates to the disinclination of the courts to substitute their judgment as to the need or prudence of prison policies for that of detention authorities, while the second relates to separation of powers considerations.

First, institutional competence. The Supreme Court has repeatedly recognized that " $[\mathrm{t}]$ he problems of prisons in America are complex and intractable" and that "[r]unning a prison is an inordinately difficult undertaking that requires expertise, planning, and the commitment of resources ...." "106 Accordingly, "[P]rison authorities are best equipped to make difficult decisions regarding prison administration."107 To put it another way, "Such considerations are peculiarly within the province and professional expertise of corrections officials." ${ }^{108}$ The courts themselves "are ill equipped to deal with the increasingly urgent problems of prison administration and reform" and the problems inherent in prison management "are not readily susceptible of resolution by decree."109

Second, the tripartite system of government. As the Supreme Court observed:

[J]udicial deference is accorded not merely because the administrator ordinarily will, as a matter of fact in a particular case, have a better grasp of his domain than the reviewing judge, but also because the operation of our correctional facilities is peculiarly the province of

101. Dawinder S. Sidhu \& Neha Singh Gohil, Civil Rights in Wartime: The Post-9/11 SikH ExPERIENCE 1 (2009).

102. Id. at 43 ; see also id. at 23 (enumerating the five Sikh articles of faith).

103. See Brown v. F.L. Roberts \& Co., 896 N.E.2d 1279, 1283 (Mass. 2008).

104. Benjamin v. Coughlin, 905 F.2d 571, 573 (2d Cir. 1990).

105. Block v. Rutherford, 468 U.S. 576, 584 (1984).

106. Brown v. Plata, 131 S. Ct. 1910, 1956 (2011) (Scalia, J., dissenting) (citation and quotations omitted) (alterations added).

107. Washington v. Harper, 494 U.S. 210, 223-24 (1990).

108. Block, 468 U.S. at 584 (citation and quotations omitted).

109. Brown, $131 \mathrm{~S}$. Ct. at 1956 (citation and quotations omitted). 
the Legislative and Executive Branches of our Government, not the Judicial. ${ }^{110}$

That is, "Prison administration is . . . a task that has been committed to the responsibility of [the legislative and executive] branches, and separation of powers concerns counsel a policy of judicial restraint."111

That said, courts are not to be silent or inert in this area. The Supreme Court has cautioned that "[p]rison walls do not form a barrier separating prison inmates" from their individual rights. ${ }^{12}$ More to the point, the Court has made clear that "[t]here is no iron curtain drawn between the Constitution and the prisons of this country." 113 Accordingly, where it is alleged that prison policies offend an inmate's rights, federal courts are duty-bound to intervene to give meaning to those protections. As the Court noted, "When a prison regulation or practice offends a fundamental constitutional guarantee, federal courts will discharge their duty to protect constitutional rights." 114 An inmate's claim that a prison grooming policy violates his or her First Amendment rights activates the federal courts' traditional function of ensuring that his or her rights have not been abridged - even if the alleged violation occurs within the specialized physical and social space of America's prisons.

In sum, plaintiffs challenging a state prison facility's inmate grooming policies have available to them constitutional and statutory remedies: the First Amendment's Free Exercise Clause and RLUIPA, respectively. In determining whether a detention facility's grooming policies are within the bounds of the law, federal courts are to give due consideration to state prison officials, who invoke security, identification, health, and order as the rationales for restrictive grooming policies. While prison officials are entitled to deference, and while individual rights do survive to some degree in the penal environment, federal courts are to still engage in meaningful judicial review as to the constitutionality and statutory permissibility of the contested prison practices or policies.

With this general backdrop in mind, it is appropriate to consider and explore the means by which the Eleventh Circuit has resolved suits

110. Bell v. Wolfish, 441 U.S. 520,548 (1979).

111. Turner v. Safley, 482 U.S. 78, 85 (1987); see also Pitts v. Thornburgh, 866 F.2d 1450, 1453 (D.C. Cir. 1989) ("'II]ssues of prison management are, both by reason of separation of powers and highly practical considerations of judicial competence, peculiarly ill-suited to judicial resolution[.] [A]ccordingly, courts should be loath to substitute their judgment for that of prison officials and administrators.").

112. Turner, 482 U.S. at 84.

113. Wolff v. McDonnell, 418 U.S. 539, 555-56 (1974).

114. Turner, 482 U.S. at 84 (citation omitted) (alteration in original). 
filed by inmates alleging that restrictive grooming policies contravene their protected religious rights under the First Amendment and RLUIPA.

\section{ELEVENTH CIRCUIT JURISPRUDENCE ON RELIGIOUS- BASED CHALLENGES TO INMATE GROOMING STANDARDS}

Despite the changes in the applicable legal standards in prisoner suits under the First Amendment or statutory law, the Eleventh Circuit has routinely upheld the restrictive grooming policies implemented by states within its jurisdiction. In 1981, the U.S. Court of Appeals for the Fifth Circuit was split, forming the newly created Eleventh Circuit. ${ }^{115}$ As the Eleventh Circuit adopted, as binding precedent, rulings of the Fifth Circuit prior to October $1,1981,{ }^{116}$ it is important to examine relevant Fifth Circuit decisions issued before this date. This overview indicates that both the original Fifth Circuit and the Eleventh Circuit that followed were consistently hostile to and dismissive of religious-based First Amendment and statutory challenges to restrictive inmate grooming standards.

\section{A. Early Free Exercise Cases}

In 1970, the unified Fifth Circuit heard a case brought by a Florida inmate who alleged that "his mustache is a gift from his creator" and that the prison's requirement that he be clean-shaven was "an infringement upon his religious liberties as guaranteed by the Constitution."117 The court rejected the plaintiff"s claim, holding that " $[t]$ he rule in question is applied to all inmates alike" and that "[f]or personal cleanliness and for personal identification under prison conditions, the rule appears to be neither unreasonable nor arbitrary." 118 In another brief per curiam opinion issued subsequently the same year, the Fifth Circuit agreed with the district court that a Free Exercise challenge to Florida's "prison's rules requiring inmates to shave twice a week and receive periodic haircuts" was "frivolous." 119 The court, following the previous opinion, reiterated that as "the haircut and shave regulations promote "cleanliness and ... personal identification' ... the state has not enforced an unrea-

115. See Honorable Stanley Marcus, Foreword, 62 U. Miami L. Rev. 969, 969 (2008) ("The United States Court of Appeals for the Eleventh Circuit was created by an Act of Congress in 1981. The Act carved [the Eleventh Circuit] out of the historic Fifth Circuit Court of Appeals ....") (citing Fifth Circuit Court of Appeals Reorganization Act of 1980, Pub. L. No. 96452, 94 Stat. 1994).

116. See Bonner v. City of Prichard, 661 F.2d 1206, 1207 (11th Cir. 1981) (en banc).

117. Brown v. Wainwright, 419 F.2d 1376, 1376 (5th Cir. 1970) (per curiam).

118. Id. at 1377.

119. Brooks v. Wainwright, 428 F.2d 652, 653 (5th Cir. 1970) (per curiam). 
sonable and arbitrary regulation." 120

In 1979, the Fifth Circuit granted short-lived procedural relief to a Muslim inmate, who asserted that the Florida prison regulation requiring "him to shave off his beard" "violated the First Amendment because his Islamic religious faith requires him to let his beard flow ...."121 The court held that the two preceding cases from 1970 were "severely undercut" by intervening Supreme Court pronouncements, such as Procunier. ${ }^{122}$ Not persuaded that it was bound to adhere to the 1970 cases in light of the altered jurisprudence in the area of First Amendment rights of prisoners, the court held that the district court "should not have dismissed plaintiff's First Amendment claim without a hearing inquiring into plaintiff's alleged sincerely held religious beliefs and into the state's justifications for its regulations." ${ }^{23}$ On remand, the plaintiff did not fare well. The district court concluded that "the no-beard rule . . . has facilitated prompt recapture of escapees in the past" and that "the prison shaving regulation, to the extent that it prohibits this plaintiff at a maximum security prison from growing a beard in conformity with his religious beliefs, is not violative of the [F]irst [A]mendment."124

This trend of rejecting inmates' substantive religious freedom challenges to prison grooming regulations continued after the formation of the Eleventh Circuit. The new federal circuit's first major foray into this field of law occurred in 1986. In that case, Abdul Hakim Jamal Nasir Shabbaz, an inmate at a Florida prison facility and a Muslim, claimed that "prison officials had violated his First Amendment right to freely exercise his Islamic faith by forcing him to shave his beard . . ." In a brief per curiam opinion, the Eleventh Circuit, effectively applying Procunier, found that the prison's "no beards" rule furthered the substantial governmental interest of ensuring authorities can identify inmates in case of escape, and that there were no alternative means to further this interest, such as an updated photograph, because "a beard is not static" - in other words, "A beard can grow longer, be cut shorter, be trimmed or altered, and even the color of it changed."126

In 1987, the Eleventh Circuit dismissed a Free Exercise claim brought by Reuven Maimon, an Orthodox Jew, who objected to Florida's inmate "require[ments] that inmates be clean shaven and that side-

120. Id. (quoting Brown, 419 F.2d at 1376).

121. Shabazz v. Barnauskas, 598 F.2d 345, 346 (5th Cir. 1979).

122. Id. at 347 n. 4 .

123. Id. at 347 .

124. Shabazz v. Barnauskas, 600 F. Supp. 712,716 (M.D. Fla. 1985).

125. Shabazz v. Bamauskas, 790 F.2d 1536, 1537 (11th Cir. 1986) (per curiam), cert. denied, 479 U.S. 1011 (1986).

126. Id. at 1540 . 
burns be unflared and no longer than the inmate's ear lobe" because "the tenets of his faith require that the male face not be shaved and that payehs or earlocks be maintained and allowed to grow freely." 27 In a short two-paragraph per curiam order, the Eleventh Circuit noted that its decision is "controlled" by its Shabazz ruling. ${ }^{128}$ As the two inmates "raised essentially the same arguments" which were rejected in Shabazz, the court denied Maimon's claim without any additional discussion or analysis. ${ }^{129}$

The same year, the Eleventh Circuit in Brightly v. Wainwright heard a consolidated action brought by a group of Florida inmates, members of the Ethopian Zion Coptic Church prohibited by their faith from shaving or cutting their hair, who asserted that the state prison's "rule requiring all inmates to shave or cut their hair violated their First Amendment right to freely exercise their religion." 130 Before the district court, the state argued that the restriction was "designed to: (1) aid in the recapture of prisoners following their escape; (2) establish a uniform grooming policy; and (3) reduce the security risk inherent in maintaining a prison." 131 In a one-page opinion, the Eleventh Circuit, finding that the cases were "controlled" by its Shabazz and Maimon decisions, held that " $[t]$ he state's grooming regulation is rationally related to a substantial government interest and that restriction is no greater than necessary to accomplish its purpose." 132

\section{B. Major Doctrinal Guideposts}

In a significant case that is noteworthy for our purposes and for its unusually extended analysis, the Eleventh Circuit rejected a religious freedom claim advanced by Anthony Martinelli, a Florida inmate and member of the Greek Orthodox religion, which does not permit adherents to cut their hair or beard. ${ }^{133}$ Martinelli alleged that the prison's "requirement that all inmates, except those who qualify for a medical exemption, be clean shaven and wear their hair cut short," infringed upon his protected free exercise rights. ${ }^{134}$ Applying the same two-part test used in Brightly, the district court ruled in Martinelli's favor, as recounted by the Eleventh Circuit:

127. Maimon v. Wainwright, 792 F.2d 133, 133 (11th Cir. 1986).

128. Id.

129. Id.

130. Brightly v. Wainwright, 814 F.2d 612, 612-13 (11th Cir. 1987) (per curiam), cert. denied, 484 U.S. 944 (1987).

131. Id. at 613 .

132. Id.

133. Martinelli v. Dugger, 817 F.2d 1499, 1501 (11 th Cir. 1987), cert. denied, 484 U.S. 1012 (1988).

134. Id. 
[A]lthough the shaving and hair length regulations further the state's interest in security, prohibiting Martinelli from growing a beard is not the least restrictive alternative because other prisoners are allowed to grow short beards for medical reasons . . . . Martinelli [must be permitted] to grow a beard to one-quarter inch in length in conformity with the medical exemption to the shaving requirement $\ldots{ }^{135}$

The Eleventh Circuit agreed that the state's interests in the regulation were substantial, and the inmate conceded this point as well. ${ }^{136}$ With respect to whether the clean-shaven and hair length requirements were the least restrictive alternative in light of the medical exemption, however, the Court reversed the district court's holding. In particular, the Eleventh Circuit determined that a religious exemption mirroring the medical exemption is not the least restrictive alternative because (1) "inmates with one-quarter inch beards [ostensibly] present a greater security risk than inmates without beards," (2) Martinelli cannot shave at all for religious reasons and he has not alleged that "cutting his beard at the skin is a greater violation of his religious beliefs than cutting his beard one-quarter of an inch from his skin," and (3) "the existence of the medical exemption does not in any way defeat [the state's] claimed interests in support of the shaving and hair length regulations," adding that the exemption is "granted only where the staff physician determines that shaving would be detrimental to the inmate's health."137 The circuit court acknowledged that "some other prison systems do not deem it necessary to impose similar regulations," but found nonetheless that "the evidence was sufficient to support a conclusion that the regulations in this case are rationally related to the substantial interests advanced."138

In a subsequent case, the Eleventh Circuit dismissed the Free Exercise and RFRA claims brought by Vincent D. Harris, a Rastafarian inmate who could not "shave, cut, or comb [his] hair or beard" in accordance with his faith. ${ }^{139}$ Harris refused, because of his religious beliefs, to submit to medium-length haircuts mandated by the Florida corrections policies, and ultimately was "forcibly removed ... from his cell, [taken] to the laundry room, and [was] restrained ... while his hair was cut by another inmate." 140 The circuit court recognized that RFRA heightened the standard used in Martinelli. ${ }^{141}$ Under RFRA, the court noted, the "[g]overnment may substantially burden a person's exercise of religion

135. Id. at 1502-03.

136. See id. at 1506 .

137. Id. at 1507 (internal quotations omitted).

138. Id. at 1506.

139. Harris v. Chapman, 97 F.3d 499, 502 (11th Cir. 1996).

140. Id.

141. See id. at 503. 
only if it demonstrates that application of the burden to the person (1) is in furtherance of a compelling governmental interest; and (2) is the least restrictive means of furthering that compelling governmental interest."142 Examining the claims under this standard, the court "assume[d]" that the prison regulation requiring Harris to be clean shaven and have short hair substantially burdened the exercise of his religion, determined "that states have a compelling interest in security and order within their prisons," and admitted it was "unable to suggest any lesser means than a hair length rule for satisfying these interests." 143

\section{Modern Post-RLUIPA Case}

As noted above, Congress enacted RLUIPA in 2000 in response to City of Boerne. A plaintiff's RLUIPA claim challenging inmate grooming policies made its way to the Eleventh Circuit in short order. In that case, Leslie Brunskill, a Native American whose "religious belief" generally prohibited the cutting of his hair, filed suit alleging that Florida's grooming policy requiring inmates to "maintain medium length hair" infringed upon his rights under the First Amendment and RLUIPA. ${ }^{144}$ As to the First Amendment, the Eleventh Circuit noted that because the court had previously held valid virtually identical grooming policies under the heightened standard applied in Harris, the regulations were permissible under the lower "reasonableness" standard applicable to Free Exercise claims under the Supreme Court's opinion in Turner. ${ }^{145}$

With respect to RLUIPA, the court noted that the statute requires the government to show, where the state substantially burdens an inmate's religious practice, "that the imposition of the burden furthers a compelling governmental interest and is the least restrictive means of furthering that interest." 146 The court determined that the state was entitled to judgment as a matter of law "since the hair length policy [is] the least restrictive means in furthering compelling governmental interests in the security, health, and safety of inmates and staff."147

In short, irrespective of the vehicle used by an inmate with a religious objection to a state correctional facility's restrictive grooming policies-the First Amendment, RFRA, or RLUIPA - the Eleventh Circuit (as currently constituted or as part of the old Fifth Circuit) has decided at every turn to uphold the substantive validity of the grooming standards. While the legal landscape has changed throughout this time, due to

142. Id. (quoting 42 U.S.C. $\S 2000 \mathrm{bb}-1$ (b) (2000)).

143. Id. at 503-04.

144. Brunskill v. Boyd, 141 F. App'x 771, 773 (11th Cir. 2005) (per curiam).

145. Id. at 774-75.

146. Id. (quoting 42 U.S.C. $\$ 2000 \mathrm{cc}-1$ (2000)).

147. Id. at 776 . 
Supreme Court decisions or statutory developments, the Eleventh Circuit has maintained its reluctance to disturb the judgments of the prison officials that the policies advance sufficiently important interests and are an appropriate means to satisfy these penological concerns. In what follows, I suggest that this approach must be revisited and replaced with a more searching standard that reflects the relevance of medical exemptions on the propriety of identical religious exemptions, the ability of most jurisdictions to meet the same penal interests without imposing restrictive grooming policies on inmates with religious views that mandate beards or long hair, and the need for particularized evidence justifying the imposition of such policies on particular inmates whose religious beliefs conflict with the policies.

\section{AN ARGUMENT FOR AN ALTERNATIVE APPROACH TO THE ELEVENTH CIRCUIT'S DEFERENTIAL SUPPORT OF RESTRICTIVE INMATE GROOMING POLICIES}

\section{A. General Principles}

Several basic principles may guide an analysis of an inmate's religious challenge to a penal institution's restrictive grooming policies. These foundational principles are difficult to square with the Eleventh Circuit's approach to cases in this area of law.

First, "Prison walls do not form a barrier separating prison inmates" from protections of their individual rights. ${ }^{148}$ Accordingly, where an inmate alleges that prison policies offend an inmate's fundamental rights, federal courts must intervene to give meaning to those protections. ${ }^{149}$ An inmate's complaint activates the federal courts' traditional function of ensuring that his or her religious rights have not been abridged.

Second, in determining whether a state's grooming policies are within the bounds of the law, federal courts are to give due consideration to the actual internal circumstances of the state's detention facilities. ${ }^{150}$ While prison officials are entitled to deference as to the management of their detention facilities, federal courts are to still engage in meaningful judicial review as to the legality of the relevant prison practices or policies. $^{151}$

148. Turner v. Safley, 482 U.S. 78,84 (1987).

149. See Procunier v. Martinez, 416 U.S. 396, 405-06 (1974).

150. See supra notes $105-11$ and accompanying text.

151. See Cruz v. Beto, 405 U.S. 319, 321 (1972) ("Federal courts sit not to supervise prisons but to enforce the constitutional rights of all 'persons,' including prisoners . . . [P]ersons in prison, like other individuals, have the right to petition the Government for redress of grievances ....."). 
Third, prison officials must put forth evidence in order for customary judicial deference to operate. In other words, deference is not a substitute for evidence itself. As one circuit court noted, prison officials are "to take the unremarkable step of providing an explanation for the policy's restrictions that takes into account any institutional need[s] . . . . That explanation, when it comes, will be afforded due deference." 152 Prison officials, who possess unique knowledge with respect to the situations existing in their detention facilities, bear responsibility to appreciably inform the courts of the specific matters taking place under their supervision. ${ }^{153}$

Fourth, as the U.S. Department of Justice recently has argued in a case involving an inmate's religious objections to Alabama's prison grooming policies, the prison's responsibility includes the duty to inform the courts as to how its policies as applied to a specific plaintiff or inmate are necessary to further its penological interests given the actual circumstances within the detention facilities. The state, the Department of Justice argued, has "the burden of showing that security, their asserted compelling interest, is actually furthered by banning ... specific Plaintiffs from having long hair." 154

Fifth, a vast majority of jurisdictions, including the Federal Bureau of Prisons, either do not have restrictive grooming policies or grant religious exemptions to inmates despite possessing the same penological interests as the jurisdictions within the Eleventh Circuit. ${ }^{155}$ This begs the question why it is necessary for the jurisdictions in the Eleventh Circuit to maintain their restrictive grooming policies if most jurisdictions allow inmates with relevant religious beliefs to be clean-shaven and grow their hair. ${ }^{156}$

152. Lovelace v. Lee, 472 F.3d 174, 190 (4th Cir. 2006); see also Department of Justice Thunderhorse Amicus Brief, supra note 25, at 9 ("Once a defendant has offered such evidence, courts have granted due deference to the expertise brought to bear in formulating the prison's policies.").

153. See Turner, 482 U.S. at 97-99 (noting lack of evidence in the record for prison officials' diminishment of prisoner rights).

154. Statement of Interest of the United States, supra note 25, at 8; see also Department of Justice Thunderhorse Amicus Brief, supra note 25, at 9 (RLUIPA requires prison officials to "do more to justify the imposition of a substantial burden on religious exercise than rely on speculation or unjustified fears," specifically they must "offer evidence . . explaining how the imposition of an identified substantial burden furthers a compelling governmental interest and why it is the least restrictive means of doing so, with reference to the circumstances presented by an individual case."); Department of Justice Garner Amicus Brief, supra note 25, at 12 ("[P]rison officials must rely on sound evidence, and not assumptions and stereotypes. The government's record evidence must consist of more than conclusory statements that a prison policy is the least restrictive means to further compelling governmental interests.").

155. See infra Appendix B.

156. See Department of Justice Thunderhorse Amicus Brief, supra note 25, at 14-15 ("[W]hen there is evidence in the record that different prison systems . . provide exemptions to a rule that 
Finally, prison officials may not punish or, under the guise of incentivizing compliance with prison regulations, condition the availability of privileges and benefits on inmates' willingness to abandon their religious practices-to do so is to effectively discipline inmates for practicing their faith. ${ }^{157}$ This general point of law has been affirmed by the United States in federal cases in the context of inmate grooming standards. ${ }^{158}$

The Eleventh Circuit's general approach to religious freedom challenges to inmate grooming standards, if continued, would violate the collective force of these basic principles. More specifically, the court would be susceptible to charges of excessively deferring to the states' explanations for their grooming policies by not recognizing that religious exemptions flow logically from medical exemptions, by not taking heed of the fact that a vast majority of other jurisdictions are able to satisfy the same penological concerns without restrictive grooming policies or with religious exemptions, and by condoning the states' failure to provide specific evidence tied to the inmates in question that the grooming policies are necessary to further their particular penological interests. It, consequently, would be credited with allowing the state to subject inmates to punishment as a direct price for following the commands of their faith. As a result of these shortcomings, the court would be said to not fulfill its central obligation to safeguard inmates' religious rights.

If allowed to stand, the Eleventh Circuit's jurisprudence would enable prison officials to bypass liability by merely restating their penological interests and without providing the courts with particularized information substantiating these interests. Meanwhile, inmates with sincere religious convictions, unable to reach the courts for meaningful judicial protection, would be compelled to either accept discipline as a condition for practicing their faith or abandon religious practices in order to be free of punishment by prison policies.

Further clarification as to the deficiencies of the Eleventh Circuit's existing approach is appropriate. As RLUIPA provides the most heightened protection for the religious rights of inmates and would be the pri-

imposes a substantial burden on religious exercise or otherwise utilize less restrictive means of furthering their interests, the courts of appeals [have] properly require[d] defendants to explain why they cannot adopt those less restrictive practices.") This is a question that the Eleventh Circuit has not, however, asked in the wake of RLUIPA, and the states within its reach have been relieved thereby of having to show why its particular circumstances necessitate the restrictive grooming policies. See supra notes $144-47$ and accompanying text.

157. See Sherbert v. Verner, 374 U.S. 398, 406 (1963) ("[T]o condition the availability of benefits upon [an individual's] willingness to violate a cardinal principle of her religious faith effectively penalizes" the individual's religious freedom).

158. See infra notes $210-11$ and accompanying text. 
mary basis for an inmate's suit challenging restrictive grooming policies, this statute is the focus of the remainder of the discussion.

\section{B. Impact of Medical Exemptions on Inmate Grooming Policies}

Under RLUIPA, the government must demonstrate that its grooming policies are in service of a "compelling governmental interest." 159 Each of the states in the Eleventh Circuit grants exemptions to the grooming policies for medical reasons. ${ }^{160}$ As noted above, states' restrictive grooming policies are justified by several interests, namely identification, security, hygiene, and order. ${ }^{161}$

These penological interests are undermined by allowing inmates with medical needs to have unshorn hair or beards of a length longer than that permitted of inmates with certain religious beliefs. Indeed, writing for the U.S. Court of Appeals for the Third Circuit, then-Judge Samuel J. Alito wrote that the government's rationale for a no-beards policy was undercut, as the policy contained a medical exemption: "We are at a loss to understand why religious exemptions threaten important city interests but medical exemptions do not." 162 A federal court similarly determined that state prison officials did not carry the burden of demonstrating a compelling penological interest where the plaintiff sought, for religious reasons, to maintain a beard of the same length already permitted for inmates with medical needs. ${ }^{163}$

159. 42 U.S.C. $\$ 2000 \mathrm{cc}-1$ (a)(1) (2000). There can be no doubt that these grooming policies may substantially burden the exercise of an inmate's religion, a threshold requirement under RLUIPA as the shaving or cutting of hair may be forbidden by an inmate's religious beliefs. See supra note 63 and accompanying text.

160. See supra notes $71,73,76$ and accompanying text.

161. See supra notes 78-84 and accompanying text. It should be noted that while the Eleventh Circuit has credited prison official's testimony "that identification of escaped inmates was made more difficult where the inmate had grown long hair and a beard because the inmate might appear substantially different with long hair and a beard than he did when he was last photographed," Martinelli v. Dugger, 817 F.2d 1499, 1506 n.24 (11th Cir. 1987), cert. denied, 484 U.S. 1012 (1988), others have not viewed identification and permissive grooming policies to be incompatible. See Luckette v. Lewis, 883 F. Supp. 471, 481 (D. Ariz. 1995) (observing that the concern that an inmate may change appearance and evade identification with lax grooming policies can be "easily rectified."). Alaska, for example, re-photographs inmates as a matter of policy, ostensibly proving that it does not find this process too onerous as a practical matter. See State Grooming Standards at 1 (ed. Rev. Ulli Klemm, Administrator, Religion \& Volunteer Services, Bureau of Inmate Services, Pa. Dep't of Corr.) (Dec. 17, 2009) (on file with author) ("If a prisoner drastically changes his or her appearance, e.g., changing hair length or color, shaving, or growing a beard or mustache, the individual shall be re- photographed for purposes of identification.").

162. Fraternal Order of Police Newark Lodge No. 12 v. City of Newark, 170 F.3d 359, 367 (3d Cir. 1999), cert. denied, 528 U.S. 817 (1999).

163. See Luckette, 883 F. Supp. at 480; see also Derek L. Gaubatz, RLUIPA at Four: Evaluating the Success and Constitutionality of RLUIPA'S Prisoner Provisions, 28 HARV. J.L. \& PuB. POL'y 501, 549 (2005) ("Allowing prisoners to grow beards for medical reasons, which also 
The proposition that a state's proffered penological interests may be undermined by other relevant circumstances is not foreign to constitutional law or to protected rights in particular. For example, the United States Jaycees, a non-profit organization that promotes individual young men's civic organizations, challenged a requirement that it admit women as regular members. ${ }^{164}$ Despite the Jaycees' argument that the exclusion of women from membership was necessary, the Supreme Court pointed out that "women affiliated with the Jaycees attend various meetings, participate in selected projects, and engage in many of the organization's social functions." 165 "[N]umerous non-members of both genders regularly participate in a substantial portion of activities central to the decision of many members to associate with one another, including many of the organization's various community programs, awards ceremonies, and recruitment meetings," the Court added. ${ }^{166}$ In short, the Court concluded, "[M]uch of the activity central to the formation and maintenance of the association involves the participation of strangers to that relationship." 167 In a separate, earlier case, the Court held that a state nursing college's interest in limiting degree-eligible students to women was "fatally undermine[d]" by the fact that men were permitted to attend and audit classes at the same college. ${ }^{168}$ Here, by the same token, the states' interests in maintaining restrictive grooming policies are difficult to square with the fact that the states provide medical exemptions for their inmates.

To be sure, the Eleventh Circuit has expressly addressed whether medical exemptions to restrictive grooming policies support inmates' Free Exercise claims. In deciding that an inmate was not entitled under law to grow his beard at the same length as that permitted for inmates receiving medical exemptions, the court in Martinelli noted, first, that "inmates with one-quarter inch beards present a greater security risk than inmates without beards." 169 But the same rationale - that facial hair equals a security risk-could be used to deny exemptions for medical reasons, though the state nonetheless permits medical exemptions.

poses the potential of doing appreciable damage to the interest of preventing contraband from being hidden in facial hair, fatally undermines [the state's] assertion that denying [inmates] the ability to grow a [shorter] beard serves a compelling interest.").

164. Roberts v. United States Jaycees, 468 U.S. 609, 614-15 (1984).

165. Id. at 621 .

166. $\mathrm{ld}$.

167. Id.

168. Miss. Univ. for Women v. Hogan, 458 U.S. 718, 730 (1982).

169. Martinelli v. Dugger, 817 F.2d 1499, 1507 (1 1 th Cir. 1987), cert. denied, 484 U.S. 1012 (1988); accord Fromer v. Scully, 874 F.2d 69, 74 (2d Cir. 1989) ("It is certainly not irrational to believe that a full beard, which may well extend for significant lengths sideways from the cheeks as well as downwards from the chin, may impede identification more than a one-inch beard."). 
Accordingly, the possibility that inmates with facial hair are a greater security risk is not an absolute bar to legitimate exemptions.

The court additionally stated that "[e]vidence before the magistrate indicated that in prisons without shaving and hair length regulations, inmates had been caught with contraband or weapons hidden in their long hair." 170 By this logic, that some inmates have hid contraband or weapons in long hair should serve as justification for denying a medical exemption to other inmates, even if those inmates requesting a medical exemption were not the inmates who were caught with contraband or weapons in their hair. There is no indication, however, that medical exemptions are denied if some other inmates have hid contraband or weapons in their hair. It is difficult to understand why this evidence can be used against individuals who seek religious exemptions, but ignored with respect to those needing medical exemptions. Moreover, the number of inmates who have medical exemptions-about $25 \%$ at the penal institution at issue in Martinelli ${ }^{171}$-is not insignificant, and further draws into question the veracity of the state's purported need to deny religious-based exemptions to restrictive grooming standards. Finally, as the Department of Justice has argued, it is not enough that the state show that some inmates with beards or long hair have presented security risks-rather, the state must prove that "specific Plaintiffs" must be specially regulated due to security threats they pose from maintaining facial hair or growing long hair. ${ }^{172} \mathrm{~A}$ generalized, guilt-by-association defense of restrictive grooming standards, in other words, should not be sufficient. Indeed, it is not for medical exemptions. Particularized evidence tied to the plaintiffs seeking a religious exemption can give rise to the denial of a religious exemption. ${ }^{173}$

170. Martinelli. 817 F.2d at 1506 n.23; accord Iron Hines v. S.C. Dep't of Corr., 148 F.3d 353, 359 (4th Cir. 1998) (denying relief under RLUIPA in light of "overwhelming" evidence that the policies were addressing "actual dangerous situations" of some inmates, but not the plaintiffs, that "had arisen" in that state's prisons).

171. See Martinelli, 817 F.2d at 1502 n.11 ("Testimony before the magistrate indicated that about 160 of the 647 inmates at the [Dade Correctional Institution] were permitted to grow beards up to one-quarter inch in length for medical reasons.").

172. Statement of Interest of the United States, supra note 25 , at 8.

173. A possible counterargument is that the prison facilities may fairly secure their penological interests based solely on the conduct of others, even if the inmates requesting religious accommodations are not themselves implicated by this conduct. This line of thinking would be attractive if it were convincing that penological concerns are the starting point for a balancing of interests. See O'Lone v. Estate of Shabazz, 482 U.S. 342, 348-49 (1987) (indicating that prison management and judicial deference to prison officials are the touchstone for an analysis of individual rights claims filed by inmates). There is reason to be concerned with the automatic, significant deference that $O^{\prime}$ Lone invites. It seems to me that the baseline should be the rights of the inmates, as individual rights presuppose government and these rights are of the American sovereign, the people. See ThE FEDERALIST No. 49 (James Madison) ("[T]he people are the only legitimate fountain of power"); ThE Federalist No. 37 (James Madison) ("[A]ll power should be 
The Eleventh Circuit's second point in Martinelli with respect to the relevance of medical exemptions as to religious exemptions is that the plaintiff in the case did not argue that trimming his beard would be permitted under his religion. ${ }^{174}$ Thus, the court reasoned, because the plaintiff did not assert that "cutting his beard at the skin is a greater violation of his religious beliefs than cutting his beard one-quarter of an inch from his skin," the court need not grant a religious exemption for the same one-quarter inch beard length that is permitted under a medical exemption. ${ }^{175}$ While it may be true for some inmates that trimming is prohibited by their faith and as a result an "all-or-nothing" option is before the courts, there are inmates whose religious beliefs permit trimming, including the one-quarter inch beard denied by the Eleventh Circuit. ${ }^{176}$ In any case, as will be argued in the next section, states within the Eleventh Circuit should not-in light of the overwhelming majority of jurisdictions that are able to meet the same interests without resorting to restrictive grooming policies or denying religious exemptions-be permitted to impose restrictive grooming policies on inmates with relevant religious beliefs in the absence of particularized evidence that the inmates in question pose risks to the penological interests.

Third, and last, the Eleventh Circuit noted that "the existence of the medical exemption does not in any way defeat [the state's] claimed interests in support of the shaving and hair length regulations," adding that the exemption is "granted only where the staff physician determines

derived from the people"); THE Federalist No. 46 (James Madison) ("[T]he ultimate authority ... resides in the people alone"); see also Thomas Paine, Common Sense 65 (Penguin Books ed., 1986) (1776) (reminding the reader that pre-formal society exists prior to structured government, though it is common to conflate the two). It is true that "[w]hen one becomes a member of [organized] society, he necessarily parts with some rights or privileges which, as an individual not affected by his relations to others, he might retain," Munn v. Illinois, 94 U.S. 113, 124 (1876), and that individual rights are further diminished in the penal context, see supra note 19 and accompanying text. Even if the individual cedes some of his natural rights to the government and if the scope of these rights is further relinquished as a function of incarceration, it does not change the fact that the residual rights, what remains, had their origins prior to government and are held by the sovereign. These rights should be the focus of cases and legal analyses in the religious freedom and inmate grooming context. In addition, to the degree that rights are diminished in a particular context, the courts exist and are instructed to protect individual rights against majoritarian overreaching, a duty that is not contingent on setting. See The Federalist No. 78 (Alexander Hamilton). Framed in this light, a restriction on religious rights premised solely on prison fear tied to the behavior of other inmates, and not only the actions of the individual inmates at issue, seems problematic for placing emphasis on official as opposed to substantive rights, and seems inconsistent with the role of courts in our system.

174. See Martinelli, 817 F.2d at 1507 ("Martinelli has at no point argued that a short, trimmed beard would be better than no beard at all.").

175. See id.

176. See, e.g., Luckette v. Lewis, 883 F. Supp. 471, 481 (D. Ariz. 1995); Monroe v. Bombard, 422 F. Supp. 211,215 (D.C.N.Y. 1976). 
that shaving would be detrimental to the inmate's health." 177 A religious exemption, like a medical exemption, is subject to a threshold inquiry as to whether the religious belief supporting the religious-based need for hair is sincere. "[P]rison officials may appropriately question whether a prisoner's religiosity, asserted as the basis for a requested accommodation, is authentic," the Supreme Court stated recently. ${ }^{178}$ That is, a preliminary barrier to relief is present in both instances. And while the penological interests may exist despite the allowance of medical exemptions, as argued above, those interests may fairly be said to be undermined by the exemptions themselves. ${ }^{179}$

These considerations may give the Eleventh Circuit pause as to the relevance of medical exemptions on the legality, under RLUIPA, of restrictive grooming policies as applied to inmates with religious beliefs requiring adherents to maintain beards or grow long hair. ${ }^{180}$

\section{Impact of Other Jurisdictions' Permissive Grooming Policies}

The previous section suggests that exemptions provided to inmates for medical reasons cut against states' interests as applied to individuals seeking religious exemptions to the same restrictive grooming policies, and introduces the proposition that the denial of religious-based exemptions must be based on particularized evidence that the plaintiffs at issue present a specific risk to a compelling penological interest. In this section, I add a layer to my argument by asserting that religious exemptions are not necessary as the justifications for restrictive grooming policies

177. Martinelli, 817 F.2d at 1507.

178. Cutter v. Wilkinson, 544 U.S. 709, 725 n.13 (2005).

179. See supra notes $162-68$ and accompanying text.

180. The Eleventh Circuit found significant testimony from a prison official "that whenever special exemptions are granted to prison rules, other inmates who have not been granted an exemption may feel resentment toward those receiving special treatment, resulting in friction between inmates." Martinelli, 817 F.2d at 1506 n.23. To the extent this is true, and the court opined it is without any citation to further evidence, see id. at 1507 , this would seem to be a reason to eliminate the restrictive grooming policies and thereby eliminate the exemption regime altogether. All inmates should be equal in terms of grooming, in other words. In any case, a speculative belief that inmates "may" feel resentment is not a concrete reason to deny a religious accommodation. See generally Opuku-Boateng v. California, 95 F.3d 1461, 1473 (9th Cir. 1996) (" $[\mathrm{H}]$ ypothetical morale problems are clearly insufficient" to defend against a religious accommodation); Anderson v. Gen. Dynamics Convair Aerospace Div., 589 F.2d 397, 402 (9th Cir. 1978) ("Even proof that employees would grumble about a particular accommodation is not enough to establish undue hardship."). But see DeHart v. Horn, 227 F.3d 47, 53 (3d Cir. 2000) ("We think it clear that a prison's interest . . . in avoiding inmate jealousy are legitimate penological concerns under Turner."). The Supreme Court credited prison officials' concerns that exempting a religious group from a work detail would engender resentment towards "perceive[d] favoritism." See O'Lone v. Estate of Shabazz, 482 U.S. 342, 353 (1987). In this case, however, certain religious inmates would not be exempt from some strenuous hardship imposed on all others, but would be free-optimally with all other inmates, or at least with those who already receive medical exemptions-to grow hair which holds special religious significance. 
themselves seem dubious in light of the fact that most other jurisdictions do not have such policies or grant religious exemptions despite having the same penological interests. Courts previously have sought to assess the extent to which jurisdictions have permitted, or prohibited, inmates from maintaining facial hair or growing long hair. A district court in 1977 , for example, found that, of forty-five states that responded to the court's survey, twenty-two states had restrictive grooming policies while twenty-one states allowed beards in all of their institutions and two allowed beards in some of their institutions. ${ }^{181}$

Today, however, the situation is much different. In contrast to the rough split between states that have restrictive grooming policies and states with permissive policies respecting grooming, my research assistants have discovered that forty-one jurisdictions (thirty-nine states, the Federal Bureau of Prisons, and the District of Columbia) now have permissive grooming policies, and only eleven have restrictive grooming policies. ${ }^{182}$ It bears noting that the permissive policies are not monolithic: in general, some expressly note, without qualification, that inmates may grow their hair in accordance with their personal preferences $^{183}$; some expressly entitle inmates to grow their hair in accordance with their religious beliefs ${ }^{184}$; and others do not have appearance restrictions but mention the prison interests, such as security and hygiene, that facilities nonetheless reserve in the event of a breach. ${ }^{185}$ On the other end of the spectrum, eleven jurisdictions possess restrictive policies that set forth express limits on hair growth or beard length, and that do not supply religious exemptions to such policies. ${ }^{186}$

The degree to which jurisdictions now permit inmates to have beards or grow long hair, as compared to those which do not, clearly and substantially favors the former jurisdictions and inmates with religious beliefs that require adherents to maintain unshorn hair. The situation has transformed on a state-by-state level. It is also fluid, and is moving specifically in the direction of permissive jurisdictions. For example, one of

181. See Martinelli, 817 F.2d at 1506 n.26 (discussing Moskowitz v. Wilkinson, 432 F. Supp. 947 (D. Conn. 1977)).

182. See Appendix B, infra.

183. See, e.g., 28 C.F.R. $\$ 551.2$ (2012).

184. See, e.g., Ariz. Dep't of Corr., InMate Regs. $\$ 704.02$ (2010), available at http://www. azcorrections.gov/Policies/700/0704.pdf.

185. See, e.g., N.H. Dep't of Corr. Policy and Procedure Directive, Safeguarding of Residents in Departmental FaCilities, No. 7.30 (2003), available at hitp://www.google.com/ $\mathrm{url}$ ? $\mathrm{sa}=\mathrm{t} \& \mathrm{rct}=\mathrm{j} \& \mathrm{q}=\& \mathrm{esrc}=\mathrm{s} \&$ source $=$ web $\& \mathrm{~cd}=1 \& \mathrm{ved}=0 \mathrm{CDYQFjAA} \& \mathrm{url}=\mathrm{http} \% 3 \mathrm{~A} \% 2 \mathrm{~F} \% 2 \mathrm{~F}$ www.wcl.american.edu\%2Fendsilence\%2Fdocuments\%2Freporting_and_confidentiality_doc_ new_hampshire.pdf\&ei=OdNCT_rxDsqdgQfeg92yCA\&usg=AFQjCNEjQr-5_LCobx1Oh3_Etvi OQ_U4yA.

186. The Alabama, Florida, and Georgia policies, discussed in Part II.B, supra, are representative examples of such policies. 
the states with the largest number of inmates, California, with 144,000 incarcerated individuals, ${ }^{187}$ agreed in 2011 to no longer enforce and change an existing policy that "prohibit[ed] inmates from wearing facial hair that extends more than one-half inch in length from the face." 188 California thus joins the Federal Bureau of Prisons, which houses over 208,000 inmates ${ }^{189}$ under a permissive regime. ${ }^{190}$ The Federal Bureau of Prisons thus "manage[s] the largest correctional system in the Nation . . . without compromising prison security, public safety, or the constitutional rights of other prisoners." 191 As a vast majority of jurisdictions, including the largest, allow inmates to grow their hair consistent with their personal preferences or religious tradition, Alabama, Florida, and Georgia's general justifications for their restrictive grooming policies lose their legal force and factual support.

In reviewing a Native American inmate's RLUIPA claim challenging California's then-restrictive grooming policies, the Ninth Circuit in 2005 pointed out that the state did not explain why prison systems with permissive grooming policies "are able to meet their indistinguishable interests without infringing on their inmates' right to freely exercise their religious beliefs." 192 This question compelled the Ninth Circuit to rule for the inmate. The same question, which attains greater weight in light of California's recent abandonment of its restrictive grooming policies, applies to the states within the Eleventh Circuit. This question, which the Ninth Circuit placed on California in the context of RLUIPA litigation, must be asked by the Eleventh Circuit of the states within its purview, to the extent that a similar claim of religious freedom is raised by an inmate subject to a policy that limits his or her ability to grow facial hair or long hair.

To be sure, this is not to advocate for a one-size-fits-all approach to prison management as it concerns religious freedom and grooming standards. ${ }^{193}$ Detention facilities invariably have varying penological con-

187. Medina, supra note 26 , at A14.

188. Basra Settlement, supra note 27 , at III 4, 9-10.

189. The number of prisoners for each of the listed jurisdictions, except for California and the District of Columbia, is reproduced from the Pew Prison Count report, supra note 28.

190. 28 C.F.R. $\$ 551.2$ (2012).

191. Cutter v. Wilkinson, 544 U.S. 709,725 (2005).

192. Warsoldier v. Woodford, 418 F.3d 989, 1000 (9th Cir. 2005); see also Department of Justice Garner Amicus Brief, supra note 25, at 12 ("A prison's claim that a specific restriction on religious exercise is the least restrictive means of advancing compelling governmental interests is significantly undermined by evidence that many other prisons, with the same compelling interests, allow the practice at issue.").

193. See generally Sandin v. Conner, 515 U.S. 472, 482 (1995) (criticizing a case which "led to the involvement of federal courts in the day-to-day management of prisons" and reiterating the preferred policy of federal courts "to afford appropriate deference and flexibility to state officials 
cerns. ${ }^{194}$ The unique circumstances in a prison facility or jurisdiction may ostensibly justify a departure from the general rule that restrictive grooming standards are not needed to meet compelling penological interests such as security or order. The question becomes when a given jurisdiction can properly deviate from the general rule.

As may be evident from the discussion thus far, a generalized, conclusory statement as to the importance of the prison officials' penological interests is insufficient to restrict an inmate's ability to grow a beard or long hair in accordance with his or her faith. As several circuit courts have noted, "[T]he state may not merely reference an interest in security or institutional order in order to justify its actions"195; "Even in light of the substantial deference given to prison authorities, the mere assertion of security or health reasons is not, by itself, enough for the Government to satisfy the compelling governmental interest requirement" ${ }^{196}$; "[M]erely stating a compelling interest does not fully satisfy [State]'s burden on this element of RLUIPA"197; and "[t]he prison administration cannot avoid court scrutiny by reflexive, rote assertions." ${ }^{198}$ For the courts to accept such general assertions by prison officials as to penological interests would be to invite courts to merely "rubber stamp or mechanically accept the judgments of prison administrators . . .." ${ }^{199}$ In other words, this form of deference here would render protected religious freedom a nullity and convert the courts into instruments of state prison policy. Such deference would allow prison officials to recite their penological interests and claim compliance with the law in the absence of actual judicial scrutiny.

Instead, as noted by the Seventh Circuit, "[T]he governmental interest asserted in support of a restrictive policy must be sufficiently articulated to allow for meaningful review of the regulation in question and its effect on the inmate's asserted rights." 200 This particularized showing must be linked to the specific plaintiffs seeking to vindicate their religious rights under the law. As the Department of Justice has argued, "While the [state has] articulated some circumstances in which

trying to manage a volatile environment.") (cited approvingly in Parrish v. Ala. Dep't of Corr., 156 F.3d 1128, 1129 n.2 (l1th Cir. 1998)).

194. See, e.g., Ragland v. Angelone, 420 F. Supp. 2d 507, 519 (W.D. Va. 2006) (noting that the same penological interests may be met by jurisdictions in different ways depending on their respective "history, inmate population, structure and funding.") (citation omitted).

195. Jova v. Smith, 582 F.3d 410,415 (2d Cir. 2009).

196. Washington v. Klem, 497 F.3d 272, 283 (3d Cir. 2007).

197. Spratt v. R.I. Dep't of Corr., 482 F.3d 33, 39 (1st Cir. 2007).

198. Shimer v. Washington, 100 F.3d 506, 510 (7th Cir. 1996) (citation and internal quotations omitted).

199. Lovelace v. Lee, 472 F.3d 174, 190 (4th Cir. 2006).

200. Caldwell v. Miller, 790 F.2d 589, 598 (7th Cir. 1986). 
long hair could conceivably be tied to potential security risks, they have not cited evidence of actual or threatened security breaches caused by nonconformity . . . with respect to these Plaintiffs." ${ }^{201}$ Without particular evidence tied to the "specific Plaintiffs," ${ }^{202}$ I suggest that the jurisdiction may not claim that its penological interests justify the abridgment of plaintiffs' religious rights. Accordingly, it seems to me that to the extent that customary deference is owed to prisons, it would be tied to evidence as to the risks associated with the specific plaintiffs or inmates bringing a religious freedom claim or otherwise seeking to engage in bona fide religious expression. ${ }^{203}$

\section{Compliance with RLUIPA}

An inmate challenging inmate grooming policies on religious grounds would likely file suit under RLUIPA, which provides the most heightened standard for religious freedom claims in the prison context. ${ }^{204}$ RLUIPA mandates that where a state substantially burdens an inmate's sincere religious practice, the state must prove that the grooming policies are the "least restrictive means" to achieve a compelling penological interest. ${ }^{205}$ As argued above, the existence of medical exemptions undermines the compelling state interests that may be advanced by the state. ${ }^{206}$ And many states, as noted above, are able to operate prisons without restrictive grooming policies or with religious exemptions. ${ }^{207}$ Particularized evidence that the specific inmates present threatened or actual security risks may, however, rebut this presumption

201. See Statement of Interest of the United States, supra note 25 , at 9 (emphasis added). As to "threatened" security risks, language in Turner suggests that prison officials need not respond only after the fact and can "anticipate security problems . . ." Turner v. Safley, 482 U.S. 78, 89 (1987). The policies, whether reactive or anticipatory, must nonetheless have some evidentiary basis. See Lovelace, 472 F.3d at 190 (requiring prison officials to elaborate and present evidence on its restrictive policies and rejecting their superficial explanations).

202. Statement of Interest of the United States, supra note 25 , at 8 .

203. The Court has explained that "[p]rison administrators [are to be] accorded wide-ranging deference in the adoption and execution of policies and practices that in their judgment are needed to preserve internal order and discipline and to maintain institutional security." Bell v. Wolfish, 441 U.S. 520, 547 (1979). The Court later clarified that this deference "requires that neither judge nor jury freely substitute their judgment for that of officials who have made a considered choice." Whitley v. Albers, 475 U.S. 312, 322 (1986). A rule which entitles prison officials to significant deference as to evidence of specific threats to compelling institutional interests as to the inmates seeking release from restrictive grooming policies seems to be consistent with this statement by the Court.

204. See Ira C. Lupu \& Robert W. Tuttle, The Forms and Limits of Religious Accommodation. The Case of RLUIPA, 32 Cardozo L. REv. 1907, 1922 (2011) ("RLUIPA . . offers much more robust protection for religious exercise than the Constitution demands for those activities.").

205. 42 U.S.C. $\$ 2000 \mathrm{cc}-1$ (a)(2) (2000).

206. See supra Part IV.B.

207. See supra Part III.C. States that create religious exemptions or that remove restrictive grooming policies may nonetheless further their interests in security by regularly inspecting 
and entitle a prison to subject the prisoner to restrictive grooming policies. $^{208}$

Two other considerations are relevant on this score. First, the courts have made it clear that inmates cannot be forced to choose between following their faith and receiving punishment from prisons on one hand, and violating the commands of their faith and avoiding punishment on the other. As Judge Guido Calabresi stated, "Precedent suggests that inmates have a right not to be disciplined for refusing to perform tasks that violate their religious beliefs." ${ }^{209}$ More directly, the Department of Justice has maintained that RLUIPA does not permit prison officials to discipline an inmate for refusing to comply with a prison's restrictive grooming policies. In particular, in the case which settled this year in favor of a Sikh inmate who is required by his faith to keep his hair unshorn, the Department of Justice noted that the prison's grooming polices "compel [the inmate] to either cut his beard and violate a central tenet of his religion or suffer increasingly severe penalties, including the deprivation of privileges . . . in violation of [his] RLUIPA rights."210 The Department of Justice explained that it participated in the case to obtain "an order under RLUIPA requiring the defendants to allow [the inmate] to wear his facial hair unshorn without penalty."211 As the government contends, RLUIPA entitles an inmate to adhere to his faith without the prospect or receipt of punishment.

The states within the Eleventh Circuit, however, subject inmates to discipline for failing to comply with facilities' restrictive grooming policies. $^{212}$ In other words, inmates must either follow the strictures of their respective religions or be forced to abandon their religious beliefs by threat of punishment. The states thus present inmates with the precise Hobson's Choice that RLUIPA prohibits. ${ }^{213}$

inmates' hair. Alaska, for example, requires its staff to 'routinely search prisoners' hair for contraband" as a matter of policy. Klemm, supra note 161 , at 1 .

208. See supra notes 201-02 and accompanying text.

209. McEachin v. McGuinnis, 357 F.3d 197, 205 (2d Cir. 2004); see also Sherbert v. Verner, 374 U.S. 398, 406 (1963).

210. Complaint in Intervention Pursuant to the Religious Land Use and Institutionalized Persons Act, 42 U.S.C. $\$ 2000$ (c) (Civil Rights), Basra v. Cate, No. CVI1-01676 SVW, II 4 (C.D. Cal. Mar. 15, 2011). See also Basra Settlement, supra note 27.

211. U.S. Dep't of Justice Civil. Rights Div., No. 45, Religious Freedom in Focus (2011), available at http://www.justice.gov/crt/spec_topics/religiousdiscrimination/newsletter/focus_45. html (emphasis added).

212. See Fla. Admin. Code Ann. r, 33-602.101(5) (2012); Ga. Comp. R. \& Regs. 125-3-2$.04(\mathrm{~g})(3)-(5)$ (2010); Corbett 12/13/11 Email, supra note 77.

213. See Abdulhaseeb v. Calbone, 600 F.3d 1301, 1325 (10th Cir. 2010) (commenting on an inmate who "has been forced to choose between violating his religious beliefs and starving to death. Whatever else might be said about RLUIPA, redressing this sort of Hobson's choice surely lies at its heart."). 
Second, courts hearing RLUIPA claims have held that restrictive grooming policies are not the "least restrictive means" required under the statute. That is, courts faced with religious-based challenges to restrictive inmate grooming polices have endorsed religious exemptions as a viable solution to the conflict between individuals' religious rights and prisons' penological interests. For example, the Ninth Circuit noted that "one alternative to [the prison's] rigid policy would be the creation of a religious exemption to the grooming policy." ${ }^{14}$ The Second Circuit similarly held that "we find that there exists an alternative means of accommodating plaintiffs' religious rights without undermining the legitimate penological interests identified by the [state]," specifically permitting the plaintiffs-inmates "to regrow their hair to any length after the initial haircut [upon arrival]." ${ }^{15}$ A federal district court also decided that "the failure to provide a religious exemption for Plaintiff's beard in the [state's] grooming policy violates RLUIPA," 216 while another concluded that the state should be enjoined from "preventing Plaintiff from growing a one quarter inch beard." 217

Accordingly, despite its rulings in Harris and Brunskill, the Eleventh Circuit would be well-advised to reconsider whether RLUIPA requires states to, at a minimum, create a religious exemption to their grooming policies identical or similar to their medical exemption. It is plausible to suggest, given the more recent rulings of federal courts, that states should no longer be permitted to hold on to their restrictive grooming policies under the theory, validated by Harris and subsequently followed in Brunskill, that they are the "least restrictive means" to furthering their penological interests. ${ }^{218}$

To be sure, some courts have suggested that creating a religious exemption would lead to a flood of inmates seeking exemptions for religious reasons. The Fifth Circuit, for instance, claimed that "[t]he number of inmates warranting a medical exemption to the grooming policy is quite small, but the number of inmates likely to seek qualification for a religious exception would be much greater." ${ }^{19}$ A district court also expressed concern that " $[t]$ he rate of religious 'conversion' would no doubt multiply exponentially, and segregation units would have little

214. Warsoldier v. Woodford, 418 F.3d 989, 999 (9th Cir. 2005).

215. Benjamin v. Coughlin, 905 F.2d 571, 577 (2d Cir. 1990).

216. Smith v. Beauclair, No. CV-03-222-C-EJL, 2006 WL 2348073, at *8 (D. Idaho Aug. 11, 2006).

217. Luckette v. Lewis, 883 F. Supp. 471, 483 (D. Ariz. 1995).

218. See May v. Baldwin, 109 F.3d 557, 564-65 (9th Cir. 1997) ("Where a prisoner challenges [a prison's] justifications, prison officials must set forth detailed evidence, tailored to the situation before the court, that identifies the failings in the alternatives advanced by the prisoner.") (emphasis added).

219. Green v. Polunsky, 229 F.3d 486, 491 (5th Cir. 2000). 
need of a barber."220

These courts' worries, however, are speculative and without an evidentiary basis. As noted above, the Federal Bureau of Prisons and a vast majority of states do not have restrictive grooming policies or have exemptions premised on religious belief. These jurisdictions have not reported or seemed to be besieged by problems associated with allowing inmates to grow their facial hair or maintain long hair for religious purposes, nor is there any indication that the states within the Eleventh Circuit themselves have these problems. Accordingly, a fear of a wave of inmates seeking religious exemptions need not preclude states from granting religious exemptions, as argued in this section, or from removing the restrictive grooming policies altogether, as suggested in previous sections.

To summarize and repeat, a court hearing a RLUIPA claim contesting the legality of restrictive inmate grooming policies should first inquire as to whether the plaintiff has proven that he or she has a sincerely held religious belief that compels him or her to grow a beard or maintain long hair; if this threshold is met, it can be safely assumed that a restrictive grooming policy requiring the cutting or shaving of hair substantially burdens the religious practice of that inmate. The state's penological interests undergirding the policies, such as security and order, are likely to be found to be compelling. The court should, however, probe the state as to why the existence of medical exemptions does not undermine these proffered interests. It should also ask why restrictive grooming policies applied to inmates with relevant religious practices are necessary, given the fact that a vast and growing majority of jurisdictions do not have such policies or affirmatively grant religious exemptions, despite having the same underlying penological interests. The state may satisfactorily defend its restrictive grooming policies by showing a particularized evidentiary basis, which is entitled to due deference, for why the specific inmate in question poses an actual or threatened risk to a compelling penological interest.

\section{CONCLUSION}

This Article explores the intersection of the right of inmates to grow beards or maintain long hair in accordance with their faith, on one hand, and the ability of prison facilities to serve their penological interests by implementing and enforcing restrictive grooming policies that require inmates to shave or trim beards, or cut hair, on the other. In particular, this Article examines the Eleventh Circuit's resolution of 
cases implicating this tension between religious freedom and prison management. Each of the states within the Eleventh Circuit has restrictive grooming policies. In choosing between inmates' religious freedom and these states' interests, the Eleventh Circuit has routinely sided with prisons. It has done so by deferring to the need for restrictive grooming policies, eschewing the impact of medical exemptions to these policies on the legal viability and practical propriety of religious exemptions to the same policies, and by not taking into account the significant and growing number of jurisdictions that do not have restrictive grooming policies or that grant religious exemptions despite sharing the same penological concerns.

This Article argues for an alternative approach to the one that the Eleventh Circuit has historically adopted. More specifically, I call for a standard in which restrictive grooming policies may not be imposed on inmates with religious beliefs that require followers to wear beards or have long hair under RLUIPA, unless there is evidence of actual or threatened risks to compelling penological interests as to the specific plaintiffs or inmates in question. This approach is more searching and is reflective of the fact that forty-one jurisdictions permit inmates to grow beards or have long hair for religious reasons, including the Federal Bureau of Prisons and California, and of the view that medical exemptions undermine the penological interests that justify the application of restrictive grooming policies to inmates with religious beliefs that conflict with the policies.

As other courts and the Department of Justice have relieved inmates from restrictive grooming policies and maximized their religious freedom as a result, the question is whether the Eleventh Circuit's approach, which enables states to subject inmates to limitations on religious expression, remains sustainable. This Article answers in the negative, and seeks thereby to give full meaning to the religious freedom that lies at the core of American fundamental liberties and that survives even in the physical and social space of penal institutions that necessarily entail a withdrawal of some freedoms. In short, religious freedom in the penal context, at least as it pertains to grooming policies, is moving towards an enlargement of the rights of inmates. I suggest, quite simply and with reference to federal cases and penal policies, that the Eleventh Circuit's jurisprudence in this area should bend in that direction as well. 


\section{APPENDIX A: IMAGE OF ALABAMA PERSONAL APPEARANCE POLICIES}

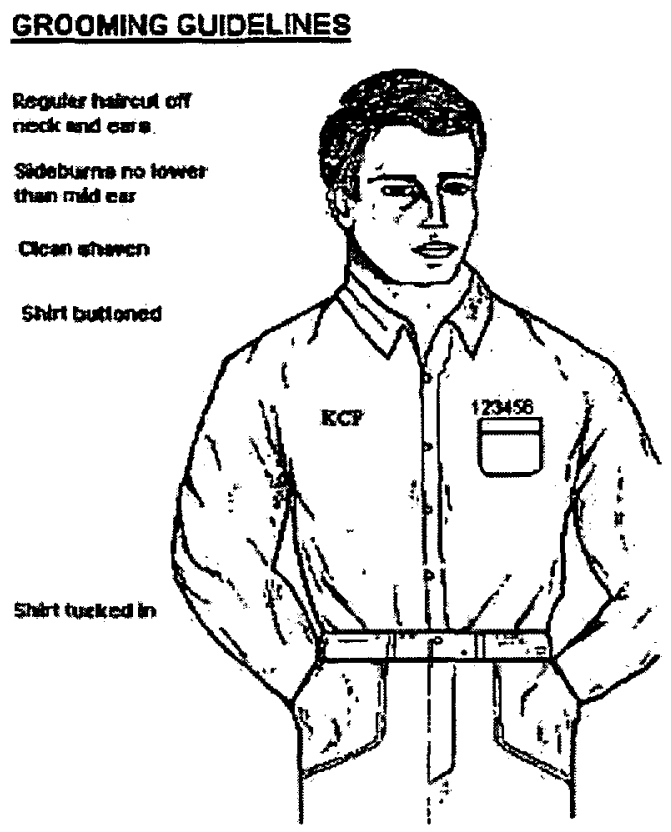




\title{
APPENDIX B: FEDERAL AND STATE INMATE GROOMING POLICIES
}

\author{
1. Jurisdictions Without Express Restrictions or \\ With Religious Exceptions to Explicit Restrictions \\ Jurisdiction (number of \\ Applicable Policies
} inmates)

1. Federal Bureau of Prisons $(208,118 \text { inmates })^{221}$

2. Alaska $(5,204)$

3. Arizona $(40,523)$

4. California $(144,000)^{225}$

5. Colorado $(22,795)$

6. Connecticut $(19,716)$

7. Delaware $(6,755)$
"An inmate may wear a mustache or beard or both. The Warden shall require an inmate with a beard to wear a beard covering when working in food service or where a beard could result in increased likelihood of work injury." 222

"A prisoner must be permitted to adopt any hair style or length, including a beard and mustache if they are kept clean.,"223

"Full beards or partial beards . . . are not authorized. Exceptions for full beards may only be granted for medical or religious reasons. Authorized beards shall be kept clean, trimmed and well-groomed at all times." 224

The policy that "prohibit[ed] inmates from wearing facial hair that extends more than onehalf inch in length from the face" is no longer enforced and will be eliminated. ${ }^{226}$ The state may require inmates 10 "maintain their facial hair in a neat and clean manner.",227

"Beards and moustaches will be permitted provided they are kept neat and clean." 228

"Hair shall be clean and appropriately groomed."229

"It is the policy of the Department of Correction to require all offenders .. . to conform to reasonable standards of grooming and attire.... No personal hygiene needs shall be denied for punitive reasons nor shall the standards conflict with the valid religious beliefs of offenders." 230

221. The number of prisoners for each of the listed jurisdictions, except for California and the District of Columbia, is reproduced from the Pew Prison Count report, supra note 28

222. 28 C.F.R. $\S 551.2$ (2011) (Mustaches and Beards).

223. Alaska Admin. Code tit. 22, $\$ 05.180(\mathrm{c})(2011)$; see also Alaska Dep't of Corr., Policies And Procedures, Sanitation AND Hygiene, 806.02(A) (1995), available at hitp:// www.correct.state.ak.us/corrections/pnp/pdf/806.02.pdf ("The Alaska DOC shall give prisoners the freedom to groom and dress as they wish as long as their appearance does not conflict with an institution's requirements for safety, security, identification, and hygiene.").

224. Ariz. Dep't of Corr., Inmate Regs. $\$ 704.02(1.3)$ (2010), available at http://www. azcorrections.gov/Policies/700/0704.pdf.

225. Medina, supra note 26 , at Al4.

226. Basra Settlement, supra note 27 , at Thl $4,9-10$.

227. Id. at 110 .

228. Colo. Dep't of Corr., Administrative Regulation, Offender Personnel: Hygiene AND GroOMING, No. 850-11 $\S$ (IV)(A)(3)(b) (2011), available at http://www.doc.state.co.us/sites/ default/files/ar/0850_11_0.pdf (citing ACA 4-4283).

229. Conn. Dep't of Corr., Administrative Directive, Inmate Property No. 6.10(36)(B) (2008), available at http://www.ct.gov/doc/LIB/doc/PDF/AD/ad0610.pdf.

230. Del. Dep't of Corr., Rights of Offenders: Standards for Offender Grooming AND ATrIRE, No. 5.3 (2009), available at http://doc.delaware.gov/pdfs/policies/policy_5-3.pdf. 

8. District of Columbia $(3,093)^{231}$

9. Hawaii $(5,891)$

10. Illinois $(45,161)$

11. Iowa $(8,485)$

12. Kansas $(8,641)$

13. Kentucky $(21,416)$

14. Maine $(2,226)$
Inmates are required to "maintain an acceptable level of personal hygiene" and must keep themselves "clean and sanitary." 232

"Hawaii does not have a department policy for grooming standards. Our practice is to encourage inmates to shave and keep their hair short for a number of reasons such as health and safety, but this is not enforced. If it clearly is a health and/or safety issue, then we deal with it on a case by case basis. My recollection is that we were advised that unless we could specifically state what the security concern is, (e.g. inmates were caught hiding contraband and their hair, specific documented health reasons, etc.) we needed to allow it for religious reasons."

"Committed persons may have any length of hair, sideburns, mustaches, or beards so long as they are kept neat and clean and do not create a security risk.,"234

"Prisoners may be required to shave or cut their hair only for sanitation." 235

"Each inmate shall keep the inmate's hair neat and clean and follow reasonable health and safety standards .... Inmates shall be allowed limited freedom in personal grooming which shall be consistent with procedures established to provide minimum personal appearance and hygiene standards appropriate to ensure safety, security, hygiene, and identification." 236

"An inmate may wear a mustache, beard, or both." 237

"Inmates can grow their hair and beards as they please (more or less) as long as they keep it clean and neat.",238

231. D.C. Dep't of Corr., Demographics and Statistics, Average Daily Population for OCTOBER 2006 THROUGH SEPTEMBER 2011, available at http://doc.dc.gov/doc/frames.asp?doc=/ doc/lib/doc/populationstats/DemographicsvvandStatistics_Oct11_1.pdf.

232. D.C. DeP'T of CoRR., InMATE HandBook, at 6 , available at http://doc.dc.gov/doc/lib/ doc/program_statements/4000/ps_4020.1c_orientation_inmate_hand_book_3-7-07.pdf. Pursuant to the National Capital Revitalization and Self-Government Improvement Act of 1997, Pub. L. No. 105-33, § 11201(b), 111 Stat. 251, 735 (1995), the District has ceded custody of its inmates to the federal government's Bureau of Prisons. The District does hold inmates "awaiting transfer to the Federal Bureau of Prisons." D.C. DeP'T of Corr., Frequently Asked Questions, Doc.DC.Gov, http://doc.dc.gov/doc/cwp/view,a,3,q,619447.asp.

233. Klemm, supra note 161 , at 6 .

234. Ill. Admin. Code tit. 20, $\$ 502.110$ (a) (2011).

235. IowA Admin. Code r. 201-50.14(356,356A)(3c) (2011).

236. Kan. Admin. Regs. § 44-12-106(a) (2011); Kan. Dep't of Corr., Internal Management Policy \& Procedure, Clothing \& Linen Issue; Inmate Hygiene and APPEARANCE, No. 12-129 (2010), available at http://www.doc.ks.gov/kdoc-policies/impp/chapter12/12129.pdf.

237. Ky. Corr., Policies and Procedures, Hair, Grooming, and ID Card Standards, No. $15.1 \S$ (II)(A)(1) (2010), available at http://corrections.ky.gov/nr/rdonlyres/03313afo-5c55-4e 6f-ac69-d24f64ba2662/0/151.pdf.

238. Klemm, supra note 161 , at 9. 
15. Maryland $(22,009)$

16. Massachusetts $(11,156)$

17. Michigan $(45,478)$

18. Minnesota $(10,064)$

19. Missouri $(30,792)$

20. Montana $(3,605)$
"Inmates must be provided a reasonable choice of selection of hair style and length and appearance (e.g., beards, moustaches, etc.) subject only to the need to ensure proper hygiene, identification, and the order and security of the facility. Such provision enhances inmate morale and respects personal identity."239

"Inmates may be permitted certain choices in personal grooming, as long as their appearance does not conflict with the institution's requirements for safety, security, identification and hygiene." 240

"Prisoners shall be encouraged to maintain a "well groomed' appearance ... . Prisoners shall be permitted to maintain head and facial hair in accordance with their personal beliefs provided that reasonable hygiene is maintained. Hair care services shall be offered at each ... institution in accordance with applicable sanitation and health requirements." 241

"Hair, including facial hair and eyebrows, must be kept clean and may not be styled or cut to contain lettering, signs or symbols." 242

"[I]ncarcerated offenders at all custody levels may have whatever hair and beard length they prefer. 1. Any offender may be required to cut their hair and beard and maintain short hair and a clean shaven face for the following reasons: a) concealing or transporting any contraband or weapon in their hair or beard; b) refusing to promptly follow staff directions with regard to a search of their hair or beard; c) having a history of escape or attempted escape; d) failing to maintain a clean and neat appearance; or e) having health, safety, or hygiene problems related to hair or beard."243

"Facilities will allow offenders freedom in personal grooming as long as their appearance does not conflict with the facility's safety, security, identification, and hygiene regulations." 244

239. Md. Comm'n on Corr. Standards, Standards, Compliance Criteria, and Compliance Explanations for Adult Community Correctional Facilities $\$ .05(\mathrm{~K})$, available at http://dpscs.maryland.gov/publicinfo/publications/pdfs/u.pdf.

240. Klemm, supra note 161 , at 9.

241. Mich. Dep't of Corr., Policy Directive, Humane Treatment and Living Conditions For Prisoners, No. 03.03.130 $\S$ (C)-(D) (2009) (citing ACA 4-4283), available at http://www.michigan.gov/documents/corrections/03_03_130_270785_7.pdf; see also BERRIEN CNTy. JaIL, InMate Rules and Regulations $\$ 13$ (2011), available at http://www.bcsheriff.org/ pdfs/26-167book.pdf.

242. Minn. Dep't of Corr., Division Directive: Offender Dress/Hygiene/Hair Care, No. $303.020 \S(\mathrm{B})(4)$ (2011) (citing ACA 4-4283), available at http://www.doc.state.mn.us/ DocPolicy2/Document/303.020.htm.

243. Klemm, supra note 161 , at 10 .

244. Mont. Dep't of Corr., Policy Directive: Offender Hygiene, Clothing, and Linen Supplies, No. DOC 4.4.1 $\S$ (IV)(A)(2) (2011) (citing ACA 4-4283), available at http://www.cor. mt.gov/content/Resources/Policy/Chapter4/4-4-1-.pdf. 
21. Nebraska $(4,490)$

22. Nevada $(12,539)$

23. New Hampshire $(2,731)$

24. New Jersey $(25,351)$

25. New Mexico $(6,578)$
"Freedom in personal grooming. This choice is limited only by institutional requirements for safety, security, identification, or hygiene."245

"Male inmates may have sideburns, beards, and moustaches, provided they are kept clean and neat, subject to provisions in this regulation. Beards, sideburns and moustaches may be required to be removed for security reasons." 246

"Personal grooming choices regarding appearance. The choice is limited only by institutional requirements for: 1 . Safety; 2. Security; 3. Identification; 4. Hygiene,247

"Inmates shall be permitted to have the hair style or length of hair they choose, including beards and mustaches, provided their hair is kept clean and does not present a safety hazard, or a health, sanitary or security problem. When the length, style or condition of an inmate's hair is found to present a safety hazard, or a health, sanitary or security problem, the inmate shall be required to trim or cut his or her hair or wear an appropriate protective head and/or beard covering." 248

"Freedom in personal grooming shall be permitted except when a valid interest justified otherwise ... . Beards and goatees are not permitted and no other facial hair is permitted .... Inmates having a sincerely held religious belief which prohibits the inmate from cutting his hair may request an exception to the grooming standards contained herein .... Inmates, for whom an exception for Sincerely Held Religious Beliefs is granted, are required to keep the hair clean, trimmed and neat." 249

245. Neb. Corr. Servs., Administrative Regulation: Inmate Rights, No. 116.01 $\S(\mathrm{III})(\mathrm{E})$ (2011) (citing ACA 4-4283), available at http://www.corrections.nebraska.gov/pdf/ar/ rights/AR\%20116.01.pdf.

246. Nev. Dep't of Corr., Administrative Regulation: Inmate Grooming and Personal Hygiene, No. $705 \$ 705.01(1)(\mathrm{A})-(\mathrm{B})$, (2010) (citing ACA 4-4283), available at http://www. doc.nv.gov/ar/pdf/AR705.pdf.

247. N.H. Dep't of Corr, Policy and Procedure Directive: Safeguarding of Residents in Departmental Facilities, no. 7.30 (2003) (citing ACA 4-4283), available at http://www. wcl.american.edu/endsilence/documents/reporting_and_confidentiality_doc_new_hampshire.pdf? rd=1. But see Belknap CNTY. Dep't of Corr., InMate HandBook, at 9 ('Sentenced Inmates must be clean-shaven at all times."), available at http://www.belknapcounty.org/pages/Belknap County_corrections/Inmate\%20Handbook.pdf

248. N.J. AdMin. CODE $\S \S 10 A: 14-2.5$ (a), (b) (2011).

249. N.M. Corr. Dep't, Inmate Grooming and Hygiene, Nos. CD-151100 \& (B), CD$151101 \S \S(\mathrm{H})(5),(\mathrm{J})(1),(\mathrm{K})(1)(2011)$ (citing ACA 4-4283), available at http://corrections. state.nm.us/policies/current/CD-151100.pdf. 
26. New York $(58,648)$

27. North Carolina $(39,871)$

28. North Dakota $(1,486)$

29. Ohio $(51,606)$

30. Oklahoma $(26,397)$
"Any reception inmate or returned parole violator who professes to be a Rastafarian, Taoist, Sikh, Native American, Orthodox Jew, or member of any other religious sect of a similar nature and refuses to have an initial haircut cannot be forced to comply with the initial haircut requirements. In addition, any reception inmate or parole violator who refuses to comply with the initial haircut regulation on religious grounds and who has a court order restraining the Department from enforcing the initial haircut regulation cannot be forced or ordered to comply with the initial haircut regulation .... An inmate may grow a beard and/or mustache, but beard/mustache hair may not exceed one (1) inch in length unless .... [ $\mathrm{t}$ ] he inmate has requested and received an exemption based upon his or her documented membership in a religion which has an established tenet against the trimming of beards." 250

"[I]nmates will be required to maintain their hair in a state of cleanliness." 251

"An inmate's hair length may not be restricted if it would violate a sincerely held religious belief unless the restriction is necessary for identification, safety, or security purposes." 252

"Inmates shall be required to be neat and well groomed, and otherwise conform their appearance to the standards set forth in this rule .... Sideburns, bangs, and other facial hair must be neatly trimmed. Facial hair must not protrude more than one-fourth inch from the skin .... If the grooming restrictions established by this rule substantially burden an inmate's sincerely held religious belief, the inmate may seek an appropriate exemption by applying for a religious accomodation [sic]."253

"Except when a valid interest justifies otherwise (as described in this procedure), facilities will allow freedom in personal grooming .... Thereafter, male hairstyles and appearances, including facial hair, will not conflict with security, sanitation, safety, or health requirements of the department. The growing, shaving, cutting, or styling of hair will remain in compliance with this procedure and with conventional community standards." 254

250. N.Y. Dep't of Corr. Servs., Directive: Inmate Grooming Standards, No. 4914 $\S \S(\mathrm{III})(\mathrm{A})(2), \quad(\mathrm{III})(\mathrm{B})(1), \quad(\mathrm{III})(\mathrm{B})(1)(\mathrm{b}) \quad(2010)$, available at http://www.docs.state.ny.us/ Directives/4914.pdf.

251. N.C. Dep't of Corr. Div. of Prisons, Clothing, Bedding, \& Personal Hygiene: Policy ANd Procedures, Ch. E .2100, $\S .2106$ (2010), available at http://www.doc.state.nc.us/ dop/policy_procedure_manual/E2100.pdf.

252. N.D. Dep't of Corr. and Rehab., North Dakota Correctional Fachity Rules Prepared by the North Dakota Department of Corrections and Rehabilitation, Rule 69, http://www.nd.gov/docr/county/inspections.html (last visited February 26, 2012).

253. Ohio Admin. Code 5120-9-25.1(A), (F), (P) (2011).

254. Okla. Dep't of Corr., Personal Hygiene and Appearance Code, No. OP-030501 $\S \S($ III), (III)(A)(2), (III)(A)(2)(a) (2011) (citing ACA 4-4283), available at http://www.doc. state.ok.us/offtech/op030501.pdf. 
31. Oregon $(14,404)$

32. Pennsylvania $(51,429)$

33. Rhode Island $(3,674)$

34. South Dakota $(3,434)$

35. Tennessee $(27,373)$

36. Utah $(6,535)$

37. Vermont $(2,221)$

38. Washington $(18,233)$

39. West Virginia $(6,367)$
"Head and facial hair must be maintained daily in a clean and neat manner.,255

"Hairstyles of different types will be permitted provided they do not conflict with the facility's procedures for safety, security, identification, and sanitation efforts .... A beard or goatee no longer than three inches; a mustache and sideburns shall be permitted provided they are kept neat and clean .... An inmate [may] request ... a hairstyle exemption based on religion . ...,256

No stated policy ${ }^{257}$

"Hair must be kept clean and neat in appearance and cannot pose a safety or sanitation threat in your work or program assignment." 258

"Inmates shall be permitted freedom in personal grooming and dress as long as their appearance does not conflict with the institution's requirements for safety, security, identification, sanitation, and hygiene." 259

"An inmate may wear a mustache or beard or both. An inmate with a beard shall wear a beard covering when participating in food service programs or where a beard could result in increased likelihood of injury."260

"There is no grooming policy for the inmate population unless it is a health risk; at that point, our medical staff intervene with doctor's orders."261

"Offenders will be permitted freedom in personal grooming as long as their appearance does not conflict with the facility's requirements for safety, security, identification, and hygiene." 262

"Facial hair will not be permitted. Medical and religious issues will be addressed on a case by case basis." 263

255. Or. Admin. R. 291-123-0015(2)(a) (2011).

256. Pa. Dep't of Corr., Policy Statement: Inmate Grooming and Barber/ Cosmetology Programs, No. DC-ADM $807 \S \S(\mathrm{A})(1)$, (A)(2)(b), (A)(2)(d) (2011), available at http://www.portal.state.pa.us/portal/server.pt/document/919466/807_inmate_hygiene_and_ grooming.pdf.

257. Telephone Interview by Douglas Spoerl with Gina Caruolo, Chief Program Dev., R.I. Dep't of Corr., (June 15, 2011).

258. S.D. Dep't of Corr., Inmate Living Guide, Personal Cleanliness and Grooming, at 7 (Sept. 22, 2011), available at http://doc.sd.gov/documents/InmateLivingGuide-2011_000.pdf.

259. Tenn. Dep't of Corr., Administrative Policies and Procedures: Hairstyles/Dress CODE/Grooming, No. $502.03 \S(\mathrm{V})$ (2006) (citing ACA 4-4283), available at http://www.tn.gov/ correction/pdf/502-03.pdf.

260. Email from Steve Gehrke, Pub. Info. Officer, Utah Dep't of Corr., to Douglas Spoerl (Jun 1, 2011 at 18:25 PM EST).

261. Email from William Lawhorn, Dir., Facility Operations, Vt. Dep't of Corr., to Douglas Spoerl (Jun 15, 2011, 16:22 PM EST).

262. Wash. Dep't of Corr., Policy: Hygiene and Grooming for Offenders, No. DOC 440.080 (2009) (citing ACA 4-4283), available at http://www.doc.wa.gov/policies/showFile. aspx? name $=440080$.

263. W. Va. Div. of Corr., Policy Directive: Inmate Grooming Standards, No. 334.01 
40. Wisconsin $(23,112)$

41. Wyoming $(2,075)$
"The department has the authority to regulate the length of hair, mustaches, and beards based upon institution health and safety concerns." 264

"Head and facial hair may be kept at any natural length provided that it is kept clean and neat in appearance at all times, does not present an undue risk to health, and is able to be searched."265

2. Jurisdictions with Explicit Restrictions without Religious Exceptions

Jurisdiction (number of inmates)

1. Alabama $(31,561)$

2. Arkansas $(15,171)$

\section{Applicable Policies}

"[Inmates] are expected to maintain a good personal appearance. Male inmates are expected to be clean shaven and neat. Mustaches and beards are not permitted. There is opportunity for haircuts so [inmates] can keep [their] hair well-groomed. Barbers are instructed in regard to proper haircuts and are not permitted to give special haircuts. Sideburns may be worn medium length and extended no longer than the middle of the ear." 266

"[Inmates may be exempted from these policies for medical reasons] based on the [decision of the state's] physician. [Exemptions] are normally issued for a certain length of time. In the case of shaving, the inmate will not be allowed to have hair longer than an 1/8th of an inch,"267

"The hair of a male resident must be worn loose and cut so as to be above the ear, with sideburns no lower than the middle of the ear lobe, and no longer in the back than the nape of the neck .... The wearing of facial hair is a privilege. When this privilege is requested and granted by the clinical staff, only a neatly trimmed mustache that does not extend beyond the corner of the mouth or over the lip is authorized. Medical staff may prescribe that residents with diagnosed dermatological problems may wear facial hair no longer than one quarter of an inch." 268

$\S(\mathrm{V})(\mathrm{A})(2)(2007)$ (citing ACA 4-4283), available at http://www.wvdoc.com/wvdoc/LinkClick. aspx?fileticket $=5 \mathrm{~V} 9 \mathrm{gW} \times \mathrm{kSaO} \times \mathrm{xo} \% 3 \mathrm{D} \& \mathrm{tabid}=104 \& \mathrm{mid}=156$.

264. Wis. Admin. CODE DOC $\$ 309.24(3)$ (b) (2011).

265. Wyo. Dep't of Corr., Policy and Procedure: Inmate Grooming, Hygiene, and SANITATION, No. $4.201 \S($ IV)(D)(5) (2006), available at http://corrections.wy.gov/Media.aspx? mediald $=37$.

266. Corbett 11/7/11 Email, supra note 75. These Alabama personal appearance policies also contain a visual depiction of these grooming requirements. See supra Appendix A.

267. Corbett 12/5/11 Email, supra note 76.

268. Ark. Dep't of Cmty. Corr., Administrative Directive: Personal Cleanliness \& GROOMING FOR RESIDENTS, No. 98-06 § (III)(B), (C) (1998), available at http://www.dcc. arkansas.gov/pdfs/policies/personalclean.pdf. 


\section{Florida $(103,915)$}

4. Georgia $(53,562)$

5. Idaho $(7,400)$

6. - Indiana $(29,818)$
Male inmates shall have their hair cut short to medium uniform length at all times with no part of the ear or collar covered. Male inmates shall be permitted to shave their entire heads in a uniform manner unless the inmate is using his hairstyle or lack thereof to demonstrate gang affiliation or otherwise pose a threat to institutional security . . . . Sideburns shall not extend beyond the bottom of the earlobes and will have straight lines with no flare at the base. All inmates shall be clean shaven, with the exception of [certain] inmates [with mental health classifications] .... Additionally an exemption from the requirement to remain clean shaven shall be granted on the basis of a medical diagnosis when it is determined by the staff physician that shaving would be detrimental to the inmate's health. Inmates granted a medical exemption from the shaving requirement may be required to keep their facial hair closely trimmed with scissors or clippers. For the purposes of this rule, 'closely trimmed' means trimmed so that no part of the facial hair exceeds the length prescribed by the physician as necessary to prevent the appearance or reappearance of skin disorders. If no specific length is prescribed, then facial hair shall be kept trimmed to within onequarter inch." 269

"Each inmate shall have a conventional haircut. Hair shall not be longer than three (3) inches; shall not extend beyond a point which would reach the collar on an ordinary shirt; and shall not cover any part of the ears or eyebrows. Inmates may wear sideburns no longer than a point even with the bottom of the ear canal. Mustaches are permitted, but shall not extend beyond the edge of the mouth and must be kept neat and trimmed at all times. Goatees, beards, and similar facial adornments are prohibited, unless medically indicated." 270

"Male offenders are allowed to grow facial hair. Facial hair must remain neatly trimmed, clean, and cannot exceed onehalf inch $\left(l^{\prime}\right)$ in length." 271

"Moustaches, sideburns and beards must be neat and clean and of reasonable length and style. Beards shall not extend below the chin more than three (3) inches and no more than one and one-half $\left(1 \frac{1}{1 / 2}\right)$ inches in length and growth on the side of the face." 272

269. Fla. Admin. Code. AnN. r. 33-602.101(4) (Care of Inmates).

270. GA. Comp. R. \& Regs. 125-2-3-.04(6) (Personal Hygiene).

271. Idaho Dep't of Corr., Standard Operating Procedure, Division of Prisons, Inmate Management: Hygiene of Offenders, Offender Barbers, and Facility HOUSEKEEPING, No. 306.02.01.001 § (5) (2008), available at http://www.idoc.idaho.gov/sites/ default/files/webfm/documents/about_us/policies_and_forms/policypublic/3060201001.pdf.

272. Ind. Dep't of Corr., Policy and Administrative Procedures, Manual of Policies and Procedures: Offender Grooming, Clothing, and Personal Hygiene, No. 02-01-104 $\S$ (IV) (2010) (citing ACA 4-4283), available at http://www.in.gov/idoc/files/02-01-104_3-1010.pdf. 
7. Louisiana $(39,780)$

8. Mississippi $(21,521)$

9. South Carolina $(24,091)$

10. Texas $(171,249)$

11. Virginia $(38,081)$
"An offender's appearance and hair style or length not conflict with institutional requirements for security, safety, identification and hygiene. These are valid penological goals . . . We control the length of the offender's hair $n$ order to accomplish safety of offenders, volunteers and staff. We do not make religious exceptions nor allow offenders to wear their hair at the length they choose. We require they keep it short, but not shaved or military style." 273

"Male inmate's hair will be kept clean and neatly cut so the hair does not fall below the collar and is not more than 3" in length. Mustaches will be neatly trimmed at all times. Beards and goatees in excess of $1 / 2$ " are not permitted for identification purposes," 274

"Inmates must be clean shaven and no inmate will be permitted to wear a beard, sideburns, goatee, etc. A mustache is authorized; however, it must be neatly trimmed and must not extend beyond the corner of the mouth or extend over the lip. 'No shave' passes are not authorized." 275

"Male offenders must be clean-shaven. No beards, mustaches or hair under the lip will be allowed.",276

"Male offenders' hair will be neatly cut no longer than above the shirt collar and around the ears. Sideburns will not extend below the middle of the ear. Hair will not be more than one inch in thickness or depth."277

* - States in the Eleventh Circuit are italicized

273. Klemm, supra note 161 , at $9-10$.

274. Miss. DeP'T of Corr., INMATE Handbook: Rights, Responsibilities, and Regulations, Ch. VI \& IV(D)(1) (2009), available at http://www.mdoc.state.ms.us/Inmate Handbook/CHAPTER\%20VI.pdf.

275. S.C. Dep't of Corr., Inmate Grooming Standards, SCDC Policy/Procedure, No. OP-22.13 (2006).

276. Tex. Dep't of Crim. Just., Offender Orientation Handbook $\S$ (III)(A)(3) (2004), available at http:/www.tdcj.state.tx.us/publications/cid/OffendOrientHbkNov04.pdf.

277. Va. Dep't of Corr., Operating Procedure: Offender Grooming and Hygiene, No. $864.1 \S(\mathrm{VI})(\mathrm{B})(1)-(3)(2010)$ (citing ACA 4-4283), available at http://www.vadoc.virginia.gov/ about/procedures/documents/800/864-1.pdf. 